REVIEW

\title{
The genetics of schizophrenia and bipolar disorder: dissecting psychosis
}

N Craddock, M C O'Donovan, M J Owen

J Med Genet 2005;42:193-204. doi: 10.1136/jmg.2005.030718

Much work has been done to identify susceptibility genes in schizophrenia and bipolar disorder. Several well established linkages have emerged in schizophrenia. Strongly supported regions are 6p24-22, 1q21-22, and $13 q 32-34$, while other promising regions include 8p2122 , 6q16-25, 22q11-12, 5q21-q33, 10p15-p11, and 1q42. Genomic regions of interest in bipolar disorder include $6 q 16-q 22,12 q 23-q 24$, and regions of 9p22p21, 10q21-q22, 14q24-q32, 13q32-q34, 22q11-q22, and chromosome 18. Recently, specific genes or loci have been implicated in both disorders and, crucially, replicated. Current evidence supports NRG1, DTNBP1, $D I S C 1, D A O A(G 72), D A O$, and RGS4 as schizophrenia susceptibility loci. For bipolar disorder the strongest evidence supports $D A O A(G 72)$ and $B D N F$. Increasing evidence suggests an overlap in genetic susceptibility across the traditional classification systems that dichotomised psychotic disorders into schizophrenia or bipolar disorder, most notably with association findings at $D A O A(G 72), D I S C 1$, and NRG1. Future identification of psychosis susceptibility genes will have a major impact on our understanding of disease pathophysiology and will lead to changes in classification and the clinical practice of psychiatry.

See end of article for authors' affiliations

Correspondence to: Nick Craddock, Department of Psychological Medicine The Henry Wellcome Building for Biomedical Research, Academic Avenue, Wales School of Medicine, Cardiff University, Heath Park, Cardiff, CF14 4XN, UK craddockn@cardiff.ac.uk

Received 5 January 2005 Accepted for publication 5 January 2005
M ental disorders are now recognised as leading causes of morbidity and affect human populations around the world. ${ }^{1}$ Genetic factors are known to play an important role in influencing susceptibility to many of the most common and important disorders. ${ }^{2}$ The functional psychoses are the most severe psychiatric disorders of adult onset and for over 100 years have been divided into two main diagnostic categories: schizophrenia and bipolar disorder.

Schizophrenia is a common disorder with a lifetime morbid risk of $1 \%$ (roughly equal in males and females), and more if spectrum disorders are included. ${ }^{3}$ It is a major cause of morbidity and consumes a great deal of long term medical and social care. It is characterised by psychotic features (delusions and hallucinations), disorganisation, dysfunction in normal affective responses, and altered cognitive functioning. Bipolar disorder is a severe mood disorder with a lifetime prevalence of $1 \%$ in both males and females. ${ }^{4}$ It is characterised by disturbances in mood ranging from extreme elation (mania) to severe depression often accompanied by psychotic features and cognitive changes. It is associated with high morbidity, service utilisation, and suicide risk. There is substantial evidence from family, twin, and adoption studies for the importance of genes in influencing susceptibility to schizophrenia and bipolar disorder and replicated findings for each disorder are now accruing from molecular genetic studies. Within this review we will briefly summarise the evidence that genes are involved in each disorder and then review the findings from molecular genetic linkage and association studies. We will end by considering the overlap in genetic findings in bipolar disorder and schizophrenia.

\section{SCHIZOPHRENIA}

\section{Genetic epidemiology}

Schizophrenia has been subjected to detailed genetic epidemiological investigation. The results of numerous family, twin, and adoption studies show conclusively that risk of illness is increased among the relatives of affected individuals and that this is the result largely of genes rather than shared environment. ${ }^{56}$ In the children and siblings of individuals with schizophrenia, the increase in risk is around 10-fold, and somewhat less than this in parents. The latter finding is probably explained by a reduction in the reproductive opportunities, drive, and possibly fertility of affected individuals. Five recent systematically ascertained studies using modern diagnostic criteria report monozygotic (MZ) concordances estimated at $41-65 \%$ compared with dizygotic (DZ) concordances of $0-28 \%$, resulting in an estimated broad heritability of $85 \%$.

While the twin and adoption literature leave little doubt that genes are important, they also point to the importance of environmental factors, since the concordance for schizophrenia in $\mathrm{MZ}$ twins is typically around $50 \%$ and heritability estimates are less than 100\%. Moreover, we should also note that liability resulting from gene-environment interaction tends to be attributed to heritability in most genetic epidemiological studies.

It is clear from genetic epidemiology that the mode of transmission is complex. ${ }^{89}$ The number of susceptibility loci, the disease risk conferred by each locus, the extent of genetic heterogeneity, and the degree of interaction among loci all remain unknown. Risch ${ }^{10}$ has calculated that the data are incompatible with the existence of any single locus conferring a relative risk in siblings 
$\left(\lambda_{\mathrm{S}}\right)$ of more than 3 and, unless extreme epistasis exists, models with at least two or three loci of $\lambda_{s} \leqslant 2$ are more plausible. It should be emphasised that these calculations are based upon the assumption of homogeneity and refer to population-wide $\lambda_{\mathrm{s}}$. It is quite possible that alleles of larger effect are operating in some groups of patients, for example families with a high density of illness. However, high density families are expected to occur by chance even under polygenic inheritance and their existence does not prove the existence of disease alleles of large effect. ${ }^{9}$

\section{Linkage findings in schizophrenia}

Several studies of schizophrenia pedigrees have found evidence for linkage at genome-wide significant level ${ }^{11}$ (see fig 1). Nevertheless, until recently, the results had, perhaps, seemed disappointing, with most positive studies falling short of genome-wide significance, and failures to replicate even the most interesting loci being the rule rather than the exception. This is probably attributable to a combination of small genetic effects and inadequate sample sizes. ${ }^{12}$ However, as the data from more than 20 genome-wide studies have accumulated and sample sizes increased, some consistent patterns have emerged.

Recently, two meta-analyses of schizophrenia linkage have been reported. Each used different methods and, unsurprisingly, obtained overlapping but somewhat different results. The study of Badner and Gershon ${ }^{13}$ supported the existence of susceptibility genes on chromosomes $8 \mathrm{p}, 13 \mathrm{q}$, and 22q, while that of Lewis et al ${ }^{14}$ most strongly favoured $2 \mathrm{q}$, but also found that the number of loci meeting the aggregate criteria for significance was much greater than the number of loci expected by chance $(p<0.001)$. Support was also obtained for regions on chromosomes $5 \mathrm{q}, 3 \mathrm{p}, 1 \mathrm{lq}, 6 \mathrm{p}, 1 \mathrm{q}, 22 \mathrm{q}, 8 \mathrm{p}, 20 \mathrm{q}$, and $14 \mathrm{p}$. Thus the $8 \mathrm{p}$ and $22 \mathrm{q}$ regions were supported by both meta-analyses but eight other regions were supported by only one. Furthermore, the region most strongly supported by the Lewis et al analysis, that on chromosome $2 \mathrm{q}$, is not one that has received strong support previously, but it is now clearly worthy of further investigation.
Previously, the economics and practicalities of hunting a susceptibility gene within a linked chromosomal region dictated that one should have virtually definitive evidence that the linkage was a true positive. With recent improvements in our knowledge of genome anatomy and in genome analysis technology, the task of positional cloning has been transformed, and, in our view, favours bolder endeavours predicated on less stringent evidence. How much evidence will be dictated largely by research funding bodies, but it seems not unreasonable to the authors to pursue a locus based upon a true type I error rate of 0.05 even in the absence of replication, with the proviso that the error rate has been rigorously assessed by simulation and allows for examination of multiple models. For many of the above regions, such studies are underway. While some of the above loci will inevitably be false positives, many will not and it is likely that several genes cloned by positional approaches will be claimed in the next few years. In the next section, we discuss those genes that have been claimed so far.

\section{Candidate gene findings in schizophrenia}

Functional candidate genes

Most of the recent findings of interest in schizophrenia have emerged from positional cloning studies, but there is also a large schizophrenia functional candidate gene literature which we will only touch on in this review. In the main, the findings have either not been replicated or have seemed so unconvincing that no attempts to do so have been made. However, meta-analyses suggest that the dopamine receptors $D R D 3,{ }^{15} D R D 2,{ }^{16}$ and the serotonergic receptor $H T R 2 A^{17}$ might confer risk, albeit with extremely small $(<1.2)$ effect sizes. We should, however, remember that if the putative associations are the result of linkage disequilibrium between the assayed markers and the true susceptibility variant, it is possible that the latter might contribute somewhat greater effects, depending upon the degree of linkage disequilibrium (LD) between the two. Among the recent claims, reports of association between GRM3 (the gene encoding metabotropic glutamate receptor type 3) and schizophrenia are among the more interesting, ${ }^{18-20}$ although in our view, the genetic data
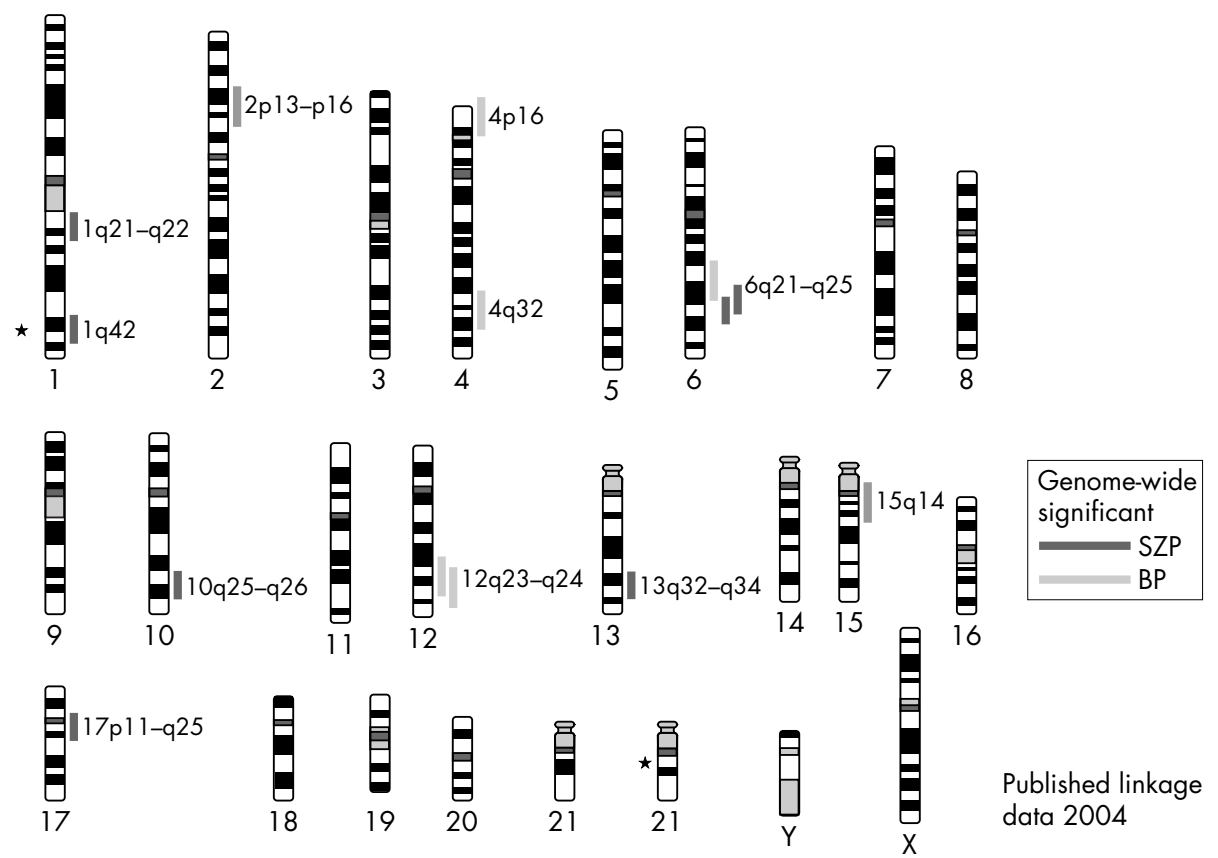

Published linkage data 2004

Figure 1 Chromosome ideograms showing locations of genome-wide significant linkages in schizophrenia and bipolar disorder. Asterisks mark the locations of chromosomal abnormalities associated with schizophrena. 
remain weak. Further study of GRM3 in particular and the glutamatergic system in general is warranted.

\section{Positional candidate genes}

Several detailed mapping studies of linked regions have implicated specific genes. The quality of the data has been variable and a number of putative susceptibility genes have yet to be clearly replicated. Here we focus on the genes where, at the time of writing, there are published follow up studies, or where we are aware of unpublished data that allow us to make a judgement about whether the gene is likely to be a true positive.

\section{Dysbindin (DTNBPI)}

Evidence implicating dystrobrevin binding protein 1 (DTNBPI), also known as dysbindin, in schizophrenia was first reported by Straub et al, ${ }^{21}$ who undertook association mapping across the linkage region on chromosome 6p22.3. Support for association rapidly followed from a largely German sample ${ }^{22}$ and in two large samples, one case-control from the UK and Ireland $^{23}$ and the other a parent-proband from Bulgaria ${ }^{24}$ studied by our own group. Although there have also been some studies in which no association was found, ${ }^{25}$ significant associations have now been published in 10 samples $^{2627}$ including an initially negative Irish sample, ${ }^{28}$ when one additional marker that defined the risk haplotype in our own UK sample was genotyped..$^{29}$ Thus, the evidence in favour of $D T N B P I$ as a susceptibility gene for schizophrenia is strong. However, there are inconsistencies between the specific risk alleles and haplotypes between studies suggesting the presence of multiple susceptibility and protective alleles, ${ }^{23}$ or that a single susceptibility allele is carried on a remarkable diversity of haplotypes even in closely related populations. As yet, no causative variant has been identified, but the absence of associated non-synonymous alleles ${ }^{23}$ suggests that disease susceptibility may depend upon variation affecting mRNA expression. This is indirectly supported by evidence for as yet unknown cis-acting polymorphisms affecting DTNBPI expression in human brain, ${ }^{29}$ and more directly by two recent studies showing reduced levels of expression of the mRNA ${ }^{30}$ and protein $^{31}$ in postmortem brain samples from patients with schizophrenia.

Although its functions are largely unknown but probably many, there is evidence that variation in DTNBPl might influence risk of schizophrenia through effects on presynaptic glutamate function. ${ }^{2631}$

\section{Neuregulin 1 (NRG1)}

$N R G 1$ was first implicated in schizophrenia in the Icelandic population after LD mapping across 8p21-22 revealed association between schizophrenia and a multi-marker haplotype at the $5^{\prime}$ end of NRG1. ${ }^{32}$ Strong evidence for association with the same haplotype was subsequently found in a large sample from Scotland, ${ }^{33}$ with considerably weaker support in our own UK sample. ${ }^{34}$ Further positive findings have emerged from Irish, ${ }^{35}$ Chinese, ${ }^{36-39}$ Bulgarian (Kirov et al, unpublished data), and South African ${ }^{40}$ samples. However, some negative findings have also been reported. ${ }^{40-43}$ Only the two deCODE studies $^{32} 33$ and our own UK study have implicated the specific Icelandic haplotype, perhaps reflecting differences in the LD structure across NRGI in European and Asian samples. ${ }^{38}$

NRG1 encodes many mRNA species and proteins. Despite detailed resequencing, ${ }^{32}$ specific susceptibility variants have not been identified, but the Icelandic haplotype points to the $5^{\prime}$ end of the gene, once again suggesting that altered expression or perhaps mRNA splicing might be involved. It is even formally possible at this stage that $N R G 1$ is not the susceptibility gene, as intron 1 contains another expressed sequence ${ }^{35}$ whose function is unknown. However, in so far as it is possible to model schizophrenia in animals, behavioural analyses of NRGI hypomorphic mice support the view that the association is related to altered NRG1 function or expression, ${ }^{44}$ a hypothesis supported by the observation of alteration in the ratios of NRGI mRNA species in schizophrenic brain. ${ }^{45}$ Just as for DTNBPl, the mechanisms by which altered NRG1 function might lead to schizophrenia are unclear. Mediation of glutamatergic mechanisms may be involved $^{32}$; however, NRG1 is thought to encode around 15 proteins with a diverse range of functions in the brain, including cell-cell signalling, Erbb receptor interactions, axon guidance, synaptogenesis, glial differentiation, myelination, and neurotransmission. ${ }^{46}$ Any of these could potentially influence susceptibility to schizophrenia.

\section{D-Amino-acid oxidase (DAO) and D-amino-acid oxidase activator (DAOA)}

Chumakov and colleagues ${ }^{47}$ undertook association mapping in the linkage region on chromosome 13q22-34. They found associations in French Canadian and Russian populations in markers around two novel genes, G72 and G30, which are overlapping but transcribed in opposite directions. G72 is a primate-specific gene expressed in the caudate and amygdala. Using yeast two-hybrid analysis, evidence for physical interaction was found between G72 and D-amino-acid oxidase $(D A O)$. DAO is expressed in human brain where it oxidises D-serine, a potent activator of NMDA glutamate receptor. Co-incubation of G72 and DAO in vitro revealed a functional interaction with G72 enhancing the activity of DAO. Consequently, G72 has now been named D-amino-acid oxidase activator (DAOA). In the same study, DAO polymorphisms were shown to be associated with schizophrenia in one of the samples, and analysis of $D A O A$ and $D A O$ variants revealed modest evidence for a statistical interaction between the loci and disease risk. Given the three levels of interaction, the authors concluded that both genes influence risk of schizophrenia through a similar pathway, and that this effect is likely to be mediated through altered NMDA receptor function.

Associations between $D A O A$ and schizophrenia have subsequently been reported in samples from Germany, ${ }^{48}$ China, ${ }^{49}$ Ashkenazi Jews, ${ }^{50}$ and both US and South Africa, ${ }^{40}$ as well as a small sample of very early onset psychosis subjects from the US. ${ }^{51}$ As before, and conceivably for similar reasons, there is no consensus concerning the specific risk alleles or haplotypes across studies. The German group also reported association between $D A O$ and schizophrenia, although with no evidence for a statistical interaction between the loci and risk of schizophrenia. At present, the published genetic evidence in support of this gene is weaker than for DTNBPI and NRG1. In our own large UK case-control sample, detailed direct and indirect association analysis (unpublished) provides support for association between schizophrenia and $D A O$ but not $D A O A$. It is possible that this reflects a weak effect size at $D A O A$ as we do find evidence for an interactive effect on risk of disease between the same markers at each locus as did Chumakov and colleagues. ${ }^{47}$

\section{Regulator of G-protein signalling 4 (RGS4)}

RGS4 maps to the putative linkage region on chromosome 1q22, but it was targeted for genetic analysis ${ }^{52}$ following a microarray based gene expression study in which decreased RGS4 expression was found in schizophrenic postmortem brain. Independent evidence for association between schizophrenia and a haplotype at the $5^{\prime}$ end of the gene was found in two samples from the USA, and while not providing significant evidence alone, inclusion of a sample from India added to the overall level of support. Positive findings have 
subsequently been reported by several other groups, ${ }^{53-55}$ but the level of support in each has been modest and the pattern of association differs between samples. RGS4 is a negative regulator of $G$ protein coupled receptors. The relationship between RGS molecules and receptor function is a promiscuous one, but of possible interest to schizophrenia. There is evidence that RGS4 modulates activity at certain serotonergic $^{56}$ and metabotropic glutamatergic receptors, ${ }^{57}$ while its own expression is modulated by dopaminergic transmission. ${ }^{58}$ Moreover, RGS4 interacts with ErbB $3,{ }^{59}$ which may be of relevance as ErbB3 is a neuregulin l receptor whose expression is down regulated in schizophrenic brains. ${ }^{46}$

\section{Others}

Finally, association analysis in single studies of CAPON (C-terminal PDZ domain ligand of neuronal nitric oxide synthase), ${ }^{60}$ PPP3CC (protein phosphatase 3, catalytic subunit), ${ }^{61}$ and TRAR4 (trace amine receptor 4), ${ }^{62}$ which map, respectively, to the $1 \mathrm{q} 22,8 \mathrm{p} 21.3$, and $6 \mathrm{q} 23.2$ linkage regions, has suggested these as possible susceptibility genes. As discussed in the original articles, each of these genes can be plausibly related to the pathogenesis of schizophrenia, but at the time of writing we are not aware of any replication data to support these hypotheses.

\section{Chromosomal abnormalities}

There have been numerous reports of associations between schizophrenia and chromosomal abnormalities ${ }^{63}$ but with two exceptions none provides convincing evidence for the location of a susceptibility gene.

$22 q 11$

Several studies have shown that adults with $22 \mathrm{ql} l$ deletions have a high risk for schizophrenia, ${ }^{64-66}$ with the largest study of adult patients to date $(n=50)$ estimating this at $24 \% .{ }^{66}$ The deletion cannot account for a high proportion of schizophrenic cases, ${ }^{67}$ but reports of linkage to 22 qll suggest that variants in genes mapping to this region might contribute to more typical cases. Current candidates include catechol-O-methyltransferase (COMT), proline dehydrogenase $(P R O D H)$, and zinc finger- and DHHC domain-containing protein 8 (ZDHHC8).

COMT has been intensively studied because of its key role in dopamine catabolism. Most studies have focussed upon a valine to methionine change at codon 158 of the brain predominant membrane-bound form of COMT (MB-COMT) and codon 108 of the soluble form (S-COMT). The valine allele confers higher activity and thermal stability to both forms of $\mathrm{COMT}^{68}$ and has been fairly consistently associated with reduced performance in tests of frontal lobe function. ${ }^{69} 70$ The results in schizophrenia have been mixed, with a recent meta-analysis ${ }^{71}$ reporting no overall evidence for association with the valine allele. Since the preparation of the COMT meta-analysis, as in an earlier study, ${ }^{72}$ four studies have found stronger evidence for association between haplotypes at COMT than for the Val/Met locus alone..$^{63-75}$ However, we have been unable to find evidence for association between the single nucleotide polymorphisms (SNPs) or haplotypes that were positive in three of the studies, ${ }^{68} 7375$ including the Val/Met polymorphism, in a study of more than 2800 individuals, including almost 1200 with schizophrenia. Moreover, it is difficult to reconcile the stronger evidence for association with haplotypes at COMT with the observation that COMT activity, at least in peripheral tissues, ${ }^{76}$ is largely dictated by the Val/Met locus, a finding that may also be true in brain. ${ }^{68}$ Thus, while the picture is confused, we consider that the evidence does not support a simple role for $\mathrm{Val} / \mathrm{Met} 158$ in susceptibility to schizophrenia, although a small effect on susceptibility cannot be excluded, nor can a role in phenotype modification.
However, it remains a possibility that variation elsewhere in $C O M T$, or in a neighbouring gene such as $A R V C F,{ }^{74}{ }^{75}$ confers susceptibility.

$P R O D H$ is also located at $22 \mathrm{qll}$ and is another functional candidate gene given that a mouse loss of function mutant exhibits behavioural abnormalities in sensorimotor gating that are analogous to those observed in schizophrenic subjects, ${ }^{77}$ and because proline dehydrogenase influences the availability of glutamate. In addition, a heterozygous deletion of the entire PRODH gene was found in a family including two schizophrenic subjects, and two heterozygous $P R O D H$ missense variants were detected in three of 63 schizophrenic patients studied by Jacquet et al. ${ }^{78}$ Evidence in favour of association between $P R O D H$ and schizophrenia has been reported by Liu and colleagues ${ }^{79}$ and by $\mathrm{Li}$ and colleagues. ${ }^{80}$ We have been unable to replicate either of these findings in large case-control and family based association samples $^{81}$ and unpublished data. Moreover, we and others ${ }^{78} 81$ have also found that the missense mutations reported by Liu and colleagues ${ }^{79}$ are no more common in schizophrenic cases than controls, while in a very large sample of Japanese subjects, $P R O D H$ deletions were not associated with schizophrenia. ${ }^{82}$ Thus the case for $P R O D H$ as a susceptibility gene for schizophrenia does not seem strong to us. However, intriguingly, the study of Jacquet and colleagues ${ }^{83}$ while failing to find association with schizophrenia (or bipolar disorder), did report association between hyperprolinaemina and schizoaffective disorder. This may suggest that $P R O D H$ may have some role in phenotype modification although this conclusion is highly tentative as the results of this study are based on a small sample and are not significant after correction for multiple testing.

Finally, there is weak genetic evidence that an SNP in ZDHHC8, a gene which encodes a putative transmembrane palmitoyl transferase, directly confers susceptibility to schizophrenia but only in females. ${ }^{84}$ The findings were particularly interesting in that study because the weak genetic evidence was bolstered by evidence that the associated SNP was functional and that sexually dimorphic effects could be seen in ZDHHC8 knockout mice, with only female mice exhibiting the phenotypes used to model schizophrenia. However, while providing supportive evidence for association, Chen and colleagues $^{85}$ found that the associated allele was the opposite to that of Mukai and colleagues, thus undermining the functional data, while also showing the effect apparently in a gender non-selective fashion, thus undermining the mouse model analogy. The only other study we are aware of is unpublished data from ourselves and others based upon almost 2000 schizophrenic subjects that do not support the finding. The findings are at present inconclusive, but given the large sample sizes studied by ourselves and the German group, together with the failure of the Chinese group to replicate the original findings in two key respects, we consider the balance of evidence for this gene still favours the null hypothesis. With somewhat more certainty, the two replication studies effectively exclude a direct role for the SNP notwithstanding the circumstantial support that it may affect the splicing of an mRNA expressed in brain regions relevant to schizophrenia. ${ }^{84}$

\section{$1 q 42$}

The other major finding based upon a chromosomal abnormality comes from an extended pedigree in which a balanced chromosomal translocation $(1 ; 11)(\mathrm{q} 42 ; \mathrm{q} 14.3)$ showed strong evidence for linkage to a fairly broad phenotype comprising schizophrenia, bipolar disorder, and recurrent depression. ${ }^{86}$ The translocation was found to disrupt two genes on chromosome 1: DISC1 and DISC2. ${ }^{86} 87$ DISC2 contains no open reading frame and may regulate 
DISC1 expression via anti-sense RNA. $^{87}$ Interestingly DISCl and 2 are located close to the chromosome 1 markers implicated in two Finnish linkage studies. ${ }^{88} 89$ There is evidence from basic science that the function of DISC1 might be relevant to schizophrenia. For example, the truncated product in the translocation family might contribute to schizophrenia by affecting neuronal functions dependent upon intact cytoskeletal regulation such as neuronal migration, neurite architecture, and intracellular transport. ${ }^{90} 91$ While interesting hypotheses, it is important to remember that translocations exert effects on genes other than those directly disrupted. For example, there are several mechanisms by which a translocation can influence the expression of neighbouring genes. Thus, in order to unequivocally implicate DISCl and/or 2 in the pathogenesis of schizophrenia, it is necessary to identify mutations or polymorphisms that are associated with schizophrenia in another population and are not in linkage disequilibrium with neighbouring genes. Four published studies have attempted to do this. Negative studies were reported by the Edinburgh group who originally identified DISCl and $2,{ }^{92}$ and by a group who focussed on the $5^{\prime}$ end of the gene in a large Japanese sample. ${ }^{93}$ However, positive findings have been reported in a large Finnish sample ${ }^{94}$ and in US samples with schizophrenia, schizoaffective disorder, and bipolar disorder. ${ }^{95}$

\section{BIPOLAR DISORDER}

\section{Genetic epidemiology}

Family, twin, and adoption studies conducted over the last 20-30 years have provided an impressive and consistent body of evidence supporting the existence of genes determining predisposition to bipolar disorder and show a gradation of risk of mood disorder as the genetic relatedness to a proband diminishes (reviewed in detail in Craddock and Jones ${ }^{96}$ ). There are methodological impediments to precise quantification, but the approximate lifetime risk of narrowly defined bipolar disorder in relatives of a bipolar proband are: unrelated member of the general population: $0.5-1.5 \%$; first degree relative $5-10 \%$ (corresponding to $\lambda_{\mathrm{S}} \sim 8$ ); monozygotic co-twin $40-70 \%$ (corresponding to $\lambda_{\mathrm{MZ}} \sim 60$ ). ${ }^{97}$ Further, relatives of bipolar probands are also at a more modest increased risk of unipolar depression (that is, depressive episodes without mania) of the order of a 2-3-fold increase of risk for a first degree relative compared with the general population. ${ }^{98}$ Estimates of heritability are high: $89 \%$ in a recent hospital register study of 67 twin pairs in the $\mathrm{UK}^{99}$ and $93 \%$ in a population register study of 19124 same-sex twin pairs in Finland. ${ }^{100}$

Occasional families may exist in which a single gene plays the major role in determining susceptibility, but most bipolar disorder involves the interaction of multiple genes (epistasis) or more complex genetic mechanisms (such as dynamic mutation or imprinting). ${ }^{96}$ Analyses using mathematical modelling suggest bipolar susceptibility genes are likely to have modest effect sizes (gene-specific sibling recurrence risk: $\left.\lambda_{\mathrm{S}} \leqslant 2\right)^{101}$ and this is consistent with findings emerging from molecular genetic studies. Bipolar disorder has not yet received the same degree of intensive study as schizophrenia, but a number of chromosomal regions have been repeatedly implicated in linkage studies and replicable findings have now been reported at some genetic loci.

\section{Linkage findings in bipolar disorder}

Systematic genome screens have been, and are being, conducted on a variety of sample sets, ranging from large densely affected pedigrees in genetic isolates to large numbers of affected sib pairs. The pattern of findings emerging is consistent with there being no gene of major effect to explain the majority of cases of bipolar disorder but several regions have been implicated repeatedly.

Two meta-analyses have been conducted with bipolar genome scan data. Badner and Gershon ${ }^{13}$ found the strongest evidence for susceptibility loci on $13 \mathrm{q}$ and $22 \mathrm{q}$ when examining seven published genome scans for bipolar disorder. However, the more extensive and detailed metaanalysis of Segurado et al ${ }^{102}$ conducted using the same bin ranking methodology as used in the meta-analysis of schizophrenia scans ${ }^{14}$ did not find genome-wide significant evidence for linkage but provided a more modest level of support for regions on chromosomes 9p22.3-21.1, 10q11.2122.1, 14q24.1-32.12, and regions of chromosome 18. This meta-analysis demonstrated lesser consistency in the findings from bipolar scans than from schizophrenia scans. ${ }^{14}$ One likely contributor to this difference is the substantially smaller number of pedigrees that were available for inclusion in the bipolar meta-analysis compared with that for schizophrenia: 370 compared with 1208 for narrowly defined illness, respectively. Another consistent difference is that it has been usual to test a broader range of (non-independent) diagnostic models in bipolar scans which require correction for multiple testing, thus reducing power for a given sample size. A further consistent difference is that a greater proportion of larger, extended pedigrees has been investigated for bipolar disorder than for schizophrenia. This may reflect a difference in the genetic architecture of the disorders. If this is the case and if there was consequently a greater heterogeneity between studies in bipolar disorder this would make detection of consistent signals in meta-analyses more difficult, a particular problem using the bin ranking method.

Four bipolar genome scans were not included in the metaanalysis of Segurado et al ${ }^{102}$ because they included less than 20 genotyped affected individuals (and, hence, failed to meet the predefined inclusion criteria used for study selection). These studies used extended pedigrees and two reported genome-wide significant linkage signals. They are shown in table 1 .

Since publication of the meta-analyses several further genome-wide scans in independent samples have been published, with several regions identified that meet genomewide significant or suggestive evidence for linkage criteria (table 2 ). Of particular note is the 6q16-q25 region which was not implicated in either meta-analysis but which is supported by one genome-wide significant and three genome-wide suggestive signals, making it one of the best supported regions for bipolar disorder.

In fig 1 we show the regions that have received genomewide significant support in at least one scan. Of particular note are the 6q16-q25 region mentioned above and the 12q23-q24 region which has two genome scans reporting genome-wide significance ${ }^{103104}$ and is also supported by linkage analysis in two pedigrees that segregate both bipolar spectrum mood disorder and Darier's disease (an autosomal dominant skin disease caused by mutations at ATP2A2 which maps at 12q23-q24.1) showing maximum LOD $>4$ at markers in this region. ${ }^{105-107}$

\section{Gene studies of bipolar disorder}

In contrast to schizophrenia, to date there has not been unambiguous demonstration of a susceptibility gene identified for bipolar disorder by positional cloning. Potentially interesting findings have come from study of functional candidates and most recently investigation of genes first implicated in schizophrenia (some of which map in linkage regions of interest in bipolar disorder). However, none of the findings yet achieve the level of support that dysbindin and $N R G 1$ have received in schizophrenia. 
Table 1 Genome scans excluded from meta-analysis because of the small number of genotyped affected individuals $(<20)$

\begin{tabular}{|c|c|c|}
\hline Reference & Sample & Best regions \\
\hline $\begin{array}{l}\text { Ewald et al }{ }^{103} \\
\text { Radhakrishna et al }{ }^{167} \\
\text { Adams et al }{ }^{168} \\
\text { Blackwood et al }\end{array}$ & $\begin{array}{l}\text { Two Danish pedigrees } \\
\text { Large Turkish pedigree } \\
\text { Large Australian pedigree } \\
\text { Large Scottish pedigree }\end{array}$ & $\begin{array}{l}12 q 24,1 p 22,4 p 16,6 q 22,10 q 26,16 p 13 \\
20 p 11-q 11 \\
4 q 35 \\
4 p 16\end{array}$ \\
\hline
\end{tabular}

\section{Functional candidates}

Functional candidate gene studies depend crucially on the choice of candidates. Inevitably this depends on the current level of understanding of disease pathophysiology. For bipolar disorder, most such studies have focussed on neurotransmitter systems influenced by medications employed in the management of the disorder, namely the dopamine, serotonin, and noradrenaline systems (reviewed in Craddock et $a l^{108}$ ). Amongst the "traditional" candidates, the genes encoding monoamine oxidase A (MAOA), tyrosine hydroxylase, catechol- $O$-methyltransferase (COMT), and the serotonin transporter (5HTT) have received particularly extensive attention. While the usual pattern for each of these genes has been for some positive studies along with perhaps an even greater number of negative replications, meta-analyses of polymorphisms of known functional relevance in three of the genes are significant at the $\mathrm{p}<0.05$ level: $M A O A,{ }^{109} C^{C O M T},{ }^{110}$ and $5 H T T,{ }^{111}{ }^{112}$ all with modest effect sizes (odds ratios (OR) «2). It is of interest that COMT has been also been implicated in schizophrenia ${ }^{73}$ and has received support from the same group in a modestly sized study of bipolar disorder. ${ }^{113}$ These findings remain to be tested in the independent, large samples that will be required to determine unambiguously whether and to what extent variation within these genes contributes to susceptibility to bipolar disorder.

Many of the candidate gene reports in the literature describe studies in modestly sized samples (a few hundred individuals). As for all complex disorders, the trend in candidate gene studies of bipolar disorder is for the use of larger samples with increased power to detect modest or small effect sizes and examination of candidate genes predicated on more sophisticated models of pathogenesis or directed by positional information from linkage studies. Replicable positive findings have started to emerge from these approaches over the last 2-3 years.

D-amino acid oxidase activator DAOA(G72)/G30 locus At least five independent datasets contribute evidence that variation at the $D A O A / G 30$ locus on chromosome $13 \mathrm{q}$ influences susceptibility to bipolar disorder. As described in the schizophrenia sections above, this locus was implicated initially as being involved in susceptibility to schizophrenia. Subsequently linkage disequilibrium at this locus was reported also with bipolar disorder in two US family samples $^{114}$ and this was replicated in a further US family sample, ${ }^{115}$ a German case-control sample, ${ }^{48}$ and our own large
UK case-control sample. ${ }^{116}$ In all studies evidence for LD came from both individual SNPs as well as multilocus haplotypes, although there is variation between studies in the SNPs and haplotypes showing LD. No pathologically relevant variant has yet been identified and the biological mechanism remains to be elucidated (see schizophrenia section above). $D A O$ has been examined in only one study of bipolar disorder $^{48}$ which found no evidence of LD. However, DAO lies in the 12q23 region of linkage interest (see fig 1) and warrants more thorough study in bipolar disorder.

\section{Brain derived neurotrophic factor (BDNF)}

A functional candidate gene that has attracted a great deal of recent interest is brain derived neurotrophic factor $(B D N F) .{ }^{117}$ BDNF is a member of the neurotrophin superfamily. Neurotrophins are synthesised in neurons as proforms that can be cleaved intra- or extracellularly and both their synthesis and secretion depends upon neuronal activity. BDNF plays an important role in promoting and modifying growth, development, and survival of neuronal populations and, in the mature nervous system, is involved in activity dependent neuronal plasticity, ${ }^{118}$ processes that are prominent in the synaptic plasticity hypothesis of mood disorder which focuses on the functional and structural changes induced by stress and antidepressants at the synaptic level. The BDNF gene lies on the reverse strand of chromosome $11 \mathrm{pl} 3$ and encodes a precursor peptide (proBDNF), which is cleaved proteolytically to form the mature protein. ${ }^{119}$ The 11 p13 chromosomal location of BDNF has been implicated in some linkage studies of bipolar disorder but not in metaanalyses of linkage studies.

Consistent with the strong evolutionary conservation of the $B D N F$ coding sequence across species, only one frequent, non-conservative polymorphism in the human BDNF gene has been identified, a single nucleotide polymorphism (SNP) at nucleotide 196 within the 5'proBDNF sequence that causes an amino acid substitution of valine to methionine at codon 66 (Val66Met). There is cross-species conservation of the precursor portion of proBDNF which is consistent with potential functional importance and it is possible that the common Val66Met polymorphism could itself have a functionally relevant effect by modifying the processing and trafficking of BDNF. ${ }^{120}$

There have been three positive reports using family based association studies of Caucasian bipolar disorder samples of European-American origin and the Val66Met SNP: two are in

Table 2 Bipolar genome scans reported subsequent to the meta-analyses

\begin{tabular}{|c|c|c|}
\hline Reference & Sample & Best regions \\
\hline $\begin{array}{l}\text { Lambert et } a l^{170} \\
\text { Fallin et } a l^{171} \\
\text { Middleton et } a l^{172} \\
\text { Dick et } a l^{173} \\
\text { Dick et } a l^{174} \text { Willour et } a l_{1}^{175} \text { Zandi et } a l^{176}\end{array}$ & $\begin{array}{l}395 \text { sib pairs in Wellcome Trust stage } 2 \text { sample } \\
41 \text { Ashkenazi pedigrees (sibs) } \\
25 \text { Portuguese origin pedigrees } \\
250 \text { NIMH pedigrees (wave } 3 \text { ) } \\
56 \text { NIMH pedigrees (wave 2) }\end{array}$ & $\begin{array}{l}\text { 6q16-q21, 4q12-q21, 9p21, 10p14-p12, 18q22 } \\
1 q 32,3 p 22,11 q 12,18 q 22 \\
6 q 22,2 q 22,10 q 21,2 p 16,4 q 22,16 p 12 \\
17 q 25,6 q 16,2 p 13,3 q 23,8 q 24 \\
11 p 15, x p 11,4 q 35,4 q 32,20 p 12,16 p 13\end{array}$ \\
\hline
\end{tabular}

Regions reported as genome-wide significant according to the criteria of Lander and Kruglyak" are shown in bold. Regions reported as genome-wide suggestive according to the criteria of Lander and Kruglyak" are shown in italics. 
adult bipolar samples ${ }^{121} 122$ and one is with a small childhood onset sample. ${ }^{123}$ All have shown over-transmission of the common Val allele. Evidence with multilocus haplotypes was stronger in one study. ${ }^{122}$ There have been four case-control association studies (of European, ${ }^{124}{ }^{125}$ Chinese, ${ }^{126}$ and Japanese origin ${ }^{127}$ ) to date, in which there is no evidence for an allelic or genotypic association. In our own UK casecontrol study of close to 1000 bipolar cases we found no significant evidence for association of the Val allele (or multilocus haplotypes) with bipolar disorder but some evidence for association within phenotypic subsets of the data (unpublished data).

Substantial additional genetic and biological work will be required to confirm (or refute) the role of BDNF in influencing susceptibility to bipolar disorder. Systematic study of variation across the whole gene is required with study in further independent samples.

\section{Other genes}

We will briefly mention three other genes that have recently been reported as "bipolar genes". Two of these are in the 22q chromosome region of interest: G-protein receptor kinase 3 (GRK3) was implicated through positional follow up of a linkage signal in a set of US pedigrees and was supported also by expression data in a rodent model of mania. ${ }^{128}$ However, this has not yet received independent support. $X B P 1$, a pivotal gene in the endoplasmic reticulum (ER) stress response, was reported to show association at a promoter polymorphism with bipolar disorder susceptibility in two small association samples. ${ }^{129}$ Some degree of circumstantial biological support for a functional role for this polymorphism came from a cellular model of the action of mood stabiliser medications. However, this report is highly likely to be a type I error because the putative functionally relevant variant was found to have no influence on susceptibility in independent family based and case-control association samples six times larger than those in the initial report. ${ }^{130}$ More promisingly, but as yet not widely tested, is the report that $P 2 X 7$, in the $12 \mathrm{q} 24$ region of linkage interest, influences susceptibility to both bipolar disorder and unipolar depression. ${ }^{131}$

\section{Closer attention to the phenotype: clinical covariates and sub-types}

As discussed elsewhere ${ }^{96}$ bipolar disorder researchers have been taking an interest in a variety of clinical sub-types and covariates over recent years as a way of testing subsets of cases with increased clinical (and hopefully genetic) homogeneity. Examples include rapid cycling (illness characterised by a high recurrence rate-at least four distinct episodes per year), ${ }^{132}$ lithium responsiveness, ${ }^{133}$ bipolar affective puerperal psychosis (triggering of bipolar episodes in females by parturition), ${ }^{134}{ }^{135}$ early age at onset, ${ }^{136}$ and occurrence of psychotic features during illness. ${ }^{137-139}$

Consideration of the occurrence of psychotic features in bipolar disorder brings us to consider the interesting and biologically important issue of the overlap in genetic findings in bipolar and schizophrenia.

\section{THE OVERLAP IN FINDINGS BETWEEN BIPOLAR DISORDER AND SCHIZOPHRENIA}

It will be clear to the reader that some of the same regions and genes have figured prominently in the sections on both schizophrenia and bipolar disorder above. Traditionally, psychiatric research in general, and the search for predisposing genes in particular, has proceeded under the assumption that schizophrenia and bipolar disorder are separate disease entities with separate underlying etiologies (and treatments), the so-called "Kraepelinian dichotomy". This distinction has pervaded Western psychiatry since Emil Kraepelin's influential nosological writings ${ }^{140}$ and survives in current operational classification systems such as DSM-IV ${ }^{141}$ and ICD 10, ${ }^{142}$ although some workers, such as Crow, have argued for a continuum approach to psychosis. ${ }^{143}$ The clinical reality is that many individuals with severe psychiatric illness have features that fall between these two "extremes" and have both prominent mood and psychotic features (often classified as "schizoaffective disorder" or some similar atypical diagnosis), raising the possibility, perhaps likelihood, that there is not a neat biological distinction between schizophrenia and bipolar disorder. This possibility finds support in several observations from genetic research, including those discussed below.

\section{Family studies}

Although family studies have demonstrated that schizophrenia and bipolar disorder tend to "breed true", ${ }^{144-146}$ families are known in which multiple cases of schizophrenia, bipolar disorder, and cases with both psychosis and mood disorder occur. ${ }^{147}$ Further, some studies have also shown statistically significant evidence that bipolar disorder occurs at increased rate in the relatives of probands with schizophrenia ${ }^{148}$ and that bipolar disorder occurs at increased frequency in the relatives of bipolar probands. ${ }^{149}$ Moreover, schizoaffective disorder has been shown to occur at increased rate in the families of probands with schizophrenia ${ }^{150}$ and bipolar disorder ${ }^{151}$ and both schizophrenia and bipolar disorder have been shown to occur at increased rate in the families of probands with schizoaffective disorder. ${ }^{151}$ Together, these family data argue for a more complex relationship between the psychoses than is reflected in the conventional dichotomous view.

\section{Twin studies}

Only one twin study has used an analysis that was unconstrained by the diagnostic hierarchy inherent in current classification systems (that is, the principle that schizophrenia "trumps" mood disorder in diagnosis). This study demonstrated a clear overlap in the genetic susceptibility to syndromally defined mania and schizophrenia. ${ }^{152}$ The findings suggested the existence of some susceptibility genes that are specific to schizophrenia, others that are specific to bipolar disorder, and yet others that influence susceptibility to schizoaffective disorder, schizophrenia, and bipolar disorder. A particularly graphic illustration of the varied expression of the same set of susceptibility genes is provided by the Maudsley triplets-a set of genetically identical triplets, two of whom had a lifetime diagnosis of schizophrenia and the third a lifetime diagnosis of bipolar disorder. ${ }^{153}$

\section{Linkage studies}

As indicated above, genetic linkage studies have identified some chromosome regions that show convergent or overlapping regions of interest in both disorders, including regions of 13q, 22q, 18, ${ }^{13} 154$ and $6 \mathrm{q}$ (fig 1). There are, however, difficulties in interpreting overlaps in linkage findings from different phenotypes because of the poor localisation of linkage signals for complex disorders and the consequent difficulty of measuring co-localisation of signals and assessing statistical evidence for significant cooccurrence. However, the hypothesis that loci exist that influence susceptibility across the schizophrenia-bipolar divide receives further support from the observation that a genome scan using families ascertained on the basis of a proband with schizoaffective disorder (a form of illness with prominent features of both schizophrenia and bipolar disorder) demonstrated genome-wide significance at lq42 and suggestive linkage at 22q11, with linkage evidence being contributed equally from "schizophrenia" families (that is, where other members had predominantly schizophrenia) and 
Table 3 Summary of current weight of evidence supporting several of the more promising genes implicated in the pathogenesis of schizophrenia and/or bipolar disorder

\begin{tabular}{llll}
\hline Gene/locus & Chromosomal location & Evidence in schizophrenia & Evidence in bipolar disorder \\
\hline Dysbindin & $6 \mathrm{p} 22$ & +++++ & + \\
Neuregulin 1 & $8 \mathrm{p} 12$ & ++++ & + \\
DISC 1 & $1 \mathrm{q} 42$ & +++ & + \\
RGS4 & $1 \mathrm{q} 23$ & ++ & ++ \\
COMT & $22 \mathrm{q} 11$ & + & ++ \\
DAOA(G72)/G30 & $13 \mathrm{q} 33$ & ++ & \\
BDNF & $11 \mathrm{p} 13$ & ++ & \\
DAO & $12 \mathrm{q} 23$ &
\end{tabular}

"bipolar families" (that is, where other members had predominantly bipolar disorder). ${ }^{155}$

\section{Gene studies}

Most persuasively, several recent reports implicate variation at the same loci as influencing susceptibility to both schizophrenia and bipolar disorder.

\section{G72(DAOA)/G30}

Currently the best supported locus for bipolar disorder is G72(DAOA)/G30 on chromosome $13 \mathrm{q}^{48}{ }^{114-116}$ which also has positive association reported in schizophrenia. ${ }^{47-50}$

\section{DISC 1}

The DISC1 locus at lq42 receives linkage support in both schizophrenia ${ }^{87-89}$ and bipolar disorder ${ }^{156}$ and, although it has been named "Disrupted in Schizophrenia", the family in which the translocation was observed contained cases of both psychosis and mood disorder; indeed the formal linkage evidence was actually somewhat greater for mood diagnoses than for psychosis diagnoses. ${ }^{87}$ Evidence for allelic association at polymorphisms at this locus has been reported for schizophrenia, bipolar disorder, and schizoaffective disorder. ${ }^{95}$

\section{NRG 1}

Neuregulin $l$ is one of the best supported schizophrenia susceptibility genes with several studies showing evidence that a so-called Icelandic "core haplotype" is associated with increased risk in Icelandic, Scottish, and UK populations. ${ }^{32-34}$ We have found that this same haplotype is significantly associated with risk for bipolar disorder and that it may exert a specific effect in the subset of functional psychosis that has both manic and mood incongruent psychotic features. ${ }^{157}$ Further support for the role of NRGI across the moodpsychosis spectrum comes from a Dutch sample in which variation at NRG1 was found to influence susceptibility only to the subset of schizophrenia cases with predominantly good outcome. ${ }^{158}$ This is the subset that typically has more features in common with mood disorders.

\section{COMT}

We have discussed the COMT locus in relation to both schizophrenia and bipolar disorder. It lies at $22 \mathrm{ql} 1$, a region implicated in both disorders. ${ }^{13}$ It is extremely likely that genetic variation in this region influences susceptibility across the psychosis spectrum, although it is not yet clear that COMT itself is the (or the major) susceptibility gene at this locus (see discussion in schizophrenia section).

These gene findings provide strong evidence that, as suggested by the family and twin data, there are genetic loci that contribute susceptibility across the Kraepelinian divide to schizophrenia, bipolar disorder, and schizoaffective disorders. These findings have important implications for classification of the major psychiatric disorders because they demonstrate an overlap in the biological basis of disorders that have, over the last 100 years, been classified as distinct entities. ${ }^{159}$ Thus, we can expect that over the coming years molecular genetics will catalyse a re-appraisal of psychiatric nosology as well as providing a path to understanding the pathophysiology that will facilitate development of improved treatments. For example, current genetic findings suggest that rather than classifying psychosis as a dichotomy, a more useful formulation may be to conceptualise a spectrum of clinical phenotype with susceptibility conferred by overlapping sets of genes. ${ }^{159}$ Already it is possible to recognise some common biological features amongst the genes implicated by current studies and tentative models have been advanced that postulate the key role of synaptic function. ${ }^{160}$

In the past psychiatric genetics has often attracted the pessimistic view that it is an area of endeavour that is so complex that advances were unlikely. However, the heritabilities of the major psychiatric disorders-schizophrenia and bipolar disorder-are amongst the highest of human illnesses. To place it in perspective, they are similar to that of height ${ }^{161}$ and type 1 diabetes, ${ }^{162}{ }^{163}$ and greater than breast cancer, ${ }^{164}$ coronary heart disease in males, ${ }^{165}$ and type II diabetes. ${ }^{166}$ Moreover, in the last $2-3$ years findings have been accruing (table 3 ) that will allow psychiatric genetics to take its place amongst the more successful areas of complex human disease genetics.

These developments can be expected to continue. This will change the practice of clinical psychiatry and have enormous potential to benefit our patients.

\section{ACKNOWLEDGEMENTS}

The authors are indebted to all the individuals who have participated our studies.

\section{Authors' affiliations}

N Craddock, M C O'Donovan, M J Owen, Department of Psychological Medicine, The Henry Wellcome Building for Biomedical Research in Wales, Wales School of Medicine, Cardiff University, Heath Park, Cardiff, CF14 4XN, UK

The authors are grateful for support for their research in the genetics of schizophrenia and bipolar disorder to the UK Medical Research Council and the Wellcome Trust

Competing interests: none declared

\section{REFERENCES}

1 Murray CJL, Lopez AD, eds. The global burden of disease: a comprehensive assessment of mortality, injuries, and risk factors in 1990 and projected to 2020. Boston: Harvard School of Public Health and the World Health Organisation, 1996

2 McGuffin P, Owen M, Gottesman II, eds. Psychiatric genetics and genomics. Oxford: Oxford University Press, 2002.

3 Gottesman II. Schizophrenia genesis: the origins of madness. New York: WH Freeman, 1991

4 Goodwin FK, Jamison KR. Manic-depressive illness. New York: Oxford University Press, 1990. 
5 McGuffin P, Owen MJ, O'Donovan MC, Thapar A, Gottesman II. Seminars in psychiatric genetics. London: Royal College of Psychiatrists, 1994:87-109.

6 Kendler KS. Schizophrenia: genetics. In: Sadock BJ, Sadock VA, eds. Kapln and Sadock's comprehensive textbook of psychiatry, Vol 1. Philadelphia, PA: Lippincott, Williams and Wilkins, 2000:1147-59.

7 Cardno AG, Gottesman II. Twin studies of schizophrenia: from bow-andarrow concordances to star wars $M x$ and functional genomics (review). Am J Med Genet 2000:97(1):12-7.

8 Gottesman II, Shields J. A polygenic theory of schizophrenia. Proc Natl Acad Sci U S A 1967;58:199-205.

9 McGue M, Gottesman II. A single dominant gene still cannot account for the transmission of schizophrenia. Arch Gen Psychiatry 1989;46:478-80.

10 Risch N. Genetic linkage and complex diseases, with special reference to psychiatric disorders. Genet Epidemiol 1990;7(1):3-16; discussion 17-45.

11 Lander E, Kruglyak L. Genetic dissection of complex traits: guidelines for interpreting and reporting linkage results. Nat Genet 1995:11:241-7.

12 Suarez BK, Hampe CL, Van Eerdewegh P. Problems of replicating linkage claims in psychiatry. In: Gershon ES, Cloninger CR, eds. Genetic approaches to mental disorders. Washington, DC: American Psychiatric Press, 1994:23-46.

13 Badner JA, Gershon ES. Meta-analysis of whole-genome linkage scans of bipolar disorder and schizophrenia. Mol Psychiatry 2002;7:405-11.

14 Lewis CM, Levinson DF, Wise LH, DeLisi LE, Straub RE, Hovatta I, Williams NM, Schwab SG, Pulver AE, Faraone SV, Brzustowicz LM, Kaufmann CA, Garver DL, Gurling HM, Lindholm E, Coon H, Moises HW, Byerley W, Shaw SH, Mesen A, Sherrington R, O'Neill FA, Walsh $D$, Kendler KS, Ekelund J, Paunio T, Lonnqvist J, Peltonen L, O'Donovan MC, Owen MJ, Wildenquer DB, Maier W, Nestadt G, Blouin JL, Antonarakis SE, Mowry BJ, Silverman JM, Crowe RR, Cloninger CR, Tsuang MT, Malaspina D, Harkavy-Friedman JM, Svrakic DM, Bassett AS, Holcomb J, Kalsi G, McQuillin A, Brynjolfson J, Sigmundsson T, Petursson H, Jazin E, Zoega T, Helgason T. Genome scan meta-analysis of schizophrenia and bipolar disorder, part II: schizophrenia. Am J Hum Genet 2003:73(1):34-48.

15 Jonsson EG, Flyckt L, Burgert E, Crocq MA, Forslund K, Mattila-Evenden M, Rylander G, Asberg M, Nimgaonkar VL, Edman G, Bjerkenstedt L, Wiesel FA, Sedvall GC. Dopamine D3 receptor gene Ser9Gly variant and schizophrenia: association study and meta-analysis. Psychiatr Genet 2003;13:1-12.

16 Glatt SJ, Faraone SV, Tsuang MT. Meta-analysis identifies an association between the dopamine D2 receptor gene and schizophrenia. Mol Psychiatry 2003:8:911-5.

17 Abdolmaleky HM, Faraone SV, Glatt SJ, Tsuang MT. Meta-analysis of association between the T102C polymorphism of the $5 \mathrm{HT} 2$ a receptor gene and schizophrenia. Schizophr Res 2004:67:53-62.

18 Marti SB, Cichon S, Propping P, Nothen M. Metabotropic glutamate receptor 3 (GRM3) gene variation is not associated with schizophrenia or bipolar affective disorder in the German population. Am J Med Genet 2002; 114:46-50.

19 Fuiji Y, Shibata H, Kikuta R, Makino C, Tani A, Hirata N, Shibata A, Ninomiya $H$, Tashiro N, Fukumaki Y. Positive associations of polymorphisms in the metabotropic glutamate receptor type 3 gene (GRM3) with schizophrenia. Psychiatr Genet 2003;13:71-6.

20 Egan MF, Straub RE, Goldberg TE, Yakub I, Callicott JH, Hariri AR, Mattay VS, Bertolino A, Hyde TM, Shannon-Weickert C, Akil M, Crook J, Vakkalanka RK, Balkissoon R, Gibbs RA, Kleinman JE, Weinberger DR. Variation in GRM3 affects cognition, prefrontal glutamate, and risk for schizophrenia. Proc Natl Acad Sci U S A 2004;101:12604-9.

21 Straub RE, Jiang Y, Maclean CJ, Ma Y, Webb BT, Myakishev MV, HarrisKerr C, Wormley B, Sadek H, Kadambi B, Cesare AJ, Gibberman A, Wang X, O'Neill FA, Walsh D, Kendler KS. Genetic variation in the 6p22.3 gene DTNBP1, the human ortholog of the mouse dysbindin gene, is associated with schizophrenia. Am J Hum Genet 2002;71(2):337-48.

22 Schwab SG, Knapp M, Mondabon S, Hallmayer J, Borrmann-Hassenbach M, Albus M, Lerer B, Rietschel M, Trixler M, Maier W, Wildenauer DB. Support for association of schizophrenia with genetic variation in the 6p22.3 gene, dysbindin, in sib-pair families with linkage and in an additional sample of triad families. Am J Hum Genet 2003;72(1):185-90.

23 Williams NM, Preece A, Morris DW, Spurlock G, Bray NJ, Stephens M, Norton N, Williams H, Clement M, Dwyer S, Curran C, Wilkinson J, Moskvina V, Waddington JL, Gill M, Corvin AP, Zammit S, Kirov G, Owen MJ, O'Donovan MC. Identification in 2 independent samples of a novel schizophrenia risk haplotype of the dystrobrevin binding protein gene (DTNBP1). Arch Gen Psychiatry 2004;61:336-44.

24 Kirov G, Ivanov D, Williams NM, Preece A, Nikolov I, Milev R, Koleva S, Dimitrova A, Toncheva D, O'Donovan MC, Owen MJ. Strong evidence for association between the dystrobrevin binding protein 1 (DTNBP1) gene and schizophrenia in 488 parent-offspring trios from Bulgaria. Biol Psychiatry 2004:55:971-5.

25 Van Den Bogaert A, Schumacher J, Schulze TG, Otte AC, Ohlraun S, Kovalenko S, Becker T, Freudenberg J, Jonsson EG, Mattila-Evenden $M$, Sedvall GC, Czerski PM, Kapelski P, Hauser J, Maier W, Rietschel M, Propping P, Nothen MM, Cichon S. The DTNBP1 (dysbindin) gene contributes to schizophrenia, depending on family history of the disease. Am J Hum Genet 2003;73:1438-43.

26 Numakawa T, Yagasaki Y, Ishimoto T, Okada T, Suzuki T, Iwata N, Ozaki N, Taguchi T, Tatsumi M, Kamijima K, Straub RE, Weinberger DR, Kunugi H, Hashimoto R. Evidence of novel neuronal functions of dysbindin, a susceptibility gene for schizophrenia. Hum Mol Genet 2004;13(21):2699-708.
27 Funke B, Finn CT, Plocik AM, Lake S, DeRosse P, Kane JM, Kucherlapati R, Malhotra AK. Association of the DTNBP1 locus with schizophrenia in a U.S. population. Am J Hum Genet 2004;75(5):891-8.

28 Morris DW, McGhee KA, Schwaiger S, Scully P, Quinn J, Meagher D, Waddington JL, Gill M, Corvin AP. No evidence for association of the dysbindin gene (DTNBP1) with schizophrenia in an Irish population-based study. Schizophr Res 2003;60:167-72.

29 Bray NJ, Buckland PR, Owen MJ, O'Donovan MC. Cis-acting variation in the expression of a high proportion of genes in human brain. Hum Genet 2003:113:149-53.

30 Weickert CS, Straub RE, McClintock BW, Matsumoto M, Hashimoto R, Hyde TM, Herman MM, Weinberger DR, Kleinman JE. Human dysbindin (DTNBP1) gene expression in normal brain and in schizophrenic prefrontal cortex and midbrain. Arch Gen Psychiatry 2004;61:544-55.

31 Talbot K, Eidem WL, Tinsley CL, Benson MA, Thompson EW, Smith RJ, Hahn CG, Siegel SJ, Trojanowski JQ, Gur RE, Blake DJ, Arnold SE. Dysbindin-1 is reduced in intrinsic, glutamatergic terminals of the hippocampal formation in schizophrenia. J Clin Invest 2004;113:1353-63.

32 Stefansson H, Sigurdsson E, Steinthorsdottir V, Bjornsdottir S, Sigmundsson T, Gosh S, Brynjolfsson J, Gunnarsdottir S, Ivarsson O, Chou $T$, Hialtason O, Birgisdottir B, Jonsson H, Gudnadottir VG Gudmundsdottir $E$, Bjornsson $A$, Ingvarsson $B$, Ingason $A$, Sigfusson $S$, Hardardottir H, Harvey RP, Lai D, Zhou M, Brunner D, Mutel V, Gonzalo A, Lemke G, Sainz J, Johannesson G, Andresson T, Gudbjartsson D, Manolescu A, Frigge ML, Gurney ME, Kong A, Gulcher JR, Petursson H, Stefansson K. Neuregulin 1 and susceptibility to schizophrenia. Am J Hum Genet 2002;71:877-92.

33 Stefansson $\mathrm{H}$, Sarginson J, Kong A, Yates P, Steinthorsdottir V, Gudfinnsson E, Gunnarsdottir S, Walker N, Petursson H, Crombie C, Ingason A, Gulcher JR, Stefansson K, St Clair D. Association of neuregulin 1 with schizophrenia confirmed in a Scottish population. Am J Hum Genet 2003;72:83-7.

34 Williams NM, Norton N, Williams $\mathrm{H}$, Ekholm B, Hamshere ML, Lindblom Y, Chowdari KV, Cardno AG, Zammit S, Jones LA, Murphy KC, Sanders RD,' McCarthy G, Gray MY, Jones G, Holmans P, Nimgaonkar V, Adolfson R, Osby U, Terenius L, Sedvall G, O'Donovan MC, Owen MJ. A systematic genomewide linkage study in 353 sib pairs with schizophrenia. Am J Hum Genet 2003;73:1355-67.

35 Corvin AP, Morris DW, McGhee K, Schwaiger S, Scully P, Quinn J, Meagher D, Clair DS, Waddington JL, Gill M. Confirmation and refinement of an 'at-risk' haplotype for schizophrenia suggests the EST cluster, Hs.97362, as a potential susceptibility gene at the Neuregulin-1 locus. Mol Psychiatry 2004;9:208-13.

36 Yang JZ, Si TM, Ruan Y, Ling YS, Han YH, Wang XL, Zhou M, Zhang HY, Kong QM, Liu C, Zhang DR, Yu YQ, Liu SZ, Ju GZ, Shu L, Ma DL, Zhang D. Association study of neuregulin 1 gene with schizophrenia. Mol Psychiatry 2003;8(7):706-9.

37 Tang JX, Chen WY, He G, Zhou J, Gu NF, Feng GY, He L. Polymorphisms within $5^{\prime}$ end of the Neuregulin 1 gene are genetically associated with schizophrenia in the Chinese population. Mol Psychiatry 2004;9:11-2.

38 Zhao X, Shi Y, Tang J, Tang R, Yu L, Gu N, Feng G, Zhu S, Liu H, Xing Y, Zhao S, Sang H, Guan Y, St Clair D, He L. A case control and family based association study of the neuregulin 1 gene and schizophrenia. J Med Genet 2004;41:31-4.

39 Li T, Stefansson H, Gudfinnsson E, Cai G, Liu X, Murray RM, Steinthorsdottir V, Januel D, Gudnadottir VG, Petursson $\mathrm{H}$, Ingason $\mathrm{A}$, Gulcher JR, Stefansson K, Collier DA. Identification of a novel neuregulin 1 at-risk haplotype in Han schizophrenia Chinese patients, but no association with the Icelandic/Scottish risk haplotype. Mol Psychiatry 2004;9:698-704.

40 Hall D Gogos JA, Karayiorgou M. The contribution of three strong candidate schizophrenia susceptibility genes in demographically distinct populations. Genes Brain Behav 2004;3:240-8.

41 Iwata N, Suzuki T, Ikeda M, Kitajima T, Yamanouchi Y, Inada T, Ozaki N. No association with the neuregulin 1 haplotype to Japanese schizophrenia. Mol Psychiatry 2004;9:126-7.

42 Thiselton DL, Webb BT, Neale BM, Ribble RC, O'Neill FA, Walsh D, Riley BP, Kendler KS. No evidence for linkage or association of neuregulin-1 (NRG1) with disease in the Irish study of high-density schizophrenia families (ISHDSF). Mol Psychiatry 2004:9:777-83.

43 Hong CJ, Huo SJ, Liao DL, Lee K, Wu JY, Tsai SJ. Case-control and familybased association studies between the neuregulin 1 (Arg38Gln) polymorphism and schizophrenia. Neurosci Lett 2004;366:158-61.

44 Stefansson H, Steinthorsdottir V, Thorgeirsson TE, Gulcher JR, Stefansson K. Neuregulin 1 and schizophrenia. Ann Med 2004;36:62-71.

45 Hashimoto R, Straub RE, Weickert CS, Hyde TM, Kleinman JE, Weinberger DR. Expression analysis of neuregulin-1 in the dorsolateral prefrontal cortex in schizophrenia. Mol Psychiatry 2004;9:299-307.

46 Corfas G, Roy K, Buxbaum JD. Neuregulin 1-erbB signaling and the molecular/cellular basis of schizophrenia. Nat Neurosci 2004:7:575-80.

47 Chumakov I, Blumenfeld M, Guerassimenko O, Cavarec L, Palicio M, Abderrahim H, Bougeueleret L, Barry C, Tanaka H, La Rosa P, Puech A, Tahri N, Cohen-Akenine A, Delabrosse S, Lissarrague S, Picard FP, Maurice K, Essioux L, Millasseau P, Grel P, Debailleul V, Simon AM, Caterina D, Dufaure I, Malekzadeh K, Belova M, Luan JJ, Bouillot M, Sambucy JL, Primas G, Saumier M, Boubkiri N, Martin-Saumier S, Nasroune M, Peixoto H, Delaye A, Pinchot V, Bastucci M, Guillou S, Chevillon M, Sainz-Fuertes R, Meguenni S, Aurich-Costa J, Cherif D, Gimalac A, van Duijn C, Gauvreau D, Ouelette G, Fortier I, Realson J, Sherbatich T, Riazanskaia N, Rogaev E, Raeymaekers P, Aerssens J, Konings F, Luyłen W, Macciardi F, Sham PC, Straub RE, Weinberger DR, Cohen N, Cohen D. Genetic and physiological data implicating the new 
human gene $G 72$ and the gene for D-amino acid oxidase in schizophrenia Proc Natl Acad Sci U S A 2002;99:13675-80.

48 Schumacher J, Jamra RA, Freudenberg J, Becker T, Ohlraun S, Otte AC, Tullius M, Kovalenko S, Bogaert AV, Maier W, Rietschel M, Propping P, Nothen MM, Cichon S. Examination of G72 and D-amino-acid oxidase as genetic risk factors for schizophrenia and bipolar affective disorder. Mol Psychiatry 2004;9:203-7.

49 Wang X, He G, Gu N, Yang J, Tang J, Chen Q, Liu X, Shen Y, Qian X, Lin W, Duan $Y$, Feng $G$, He L. Association of G72/G30 with schizophrenia in the Chinese population. Biochem Biophys Res Commun 2004;319:1281-6.

50 Korostishevsky M, Kaganovich M, Cholostoy A, Ashkenazi M, Ratner $Y$, Dahary D, Bernstein J, Bening-Abu-Shach U, Ben-Asher E, Lancet D, Ritsner M, Navon R. Is the G72/G30 locus associated with schizophrenia? single nucleotide polymorphisms, haplotypes, and gene expression analysis. Biol Psychiatry 2004;56(3): 169-76.

51 Addington AM, Gornick M, Sporn AL, Gogtay N, Greenstein D, Lenane M, Gochman P, Baker N, Balkissoon R, Vakkalanka RK, Weinberger DR, Straub RE, Rapoport JL. Polymorphisms in the 13q33.2 gene G72/G30 are associated with childhood-onset schizophrenia and psychosis not otherwise specified. Biol Psychiatry 2004;55:976-80

52 Chowdari KV, Mirnics K, Semwal P, Wood J, Lawrence E, Bhatia T, Deshpande SN, Thelma BK, Ferrell RE, Middleton FA, Devlin B, Levitt P, Lewis DA, Nimgaonkar VL. Association and linkage analyses of RGS4 polymorphisms in schizophrenia. Hum Mol Genet 2002;11:1373-80.

53 Williams NM, Preece A, Spurlock G, Norton N, Williams HJ, McCreadie RG Buckland P, Sharkey V, Chowdari KV, Zammit S, Nimgaonkar V, Kirov G, Owen MJ, O'Donovan MC. Support for RGS4 as a susceptibility gene for schizophrenia. Biol Psychiatry 2004;55:192-5.

54 Chen X, Dunham C, Kendler S, Wang X, O'Neill FA, Walsh D, Kendler KS. Regulator of G-protein signaling 4 (RGS4) gene is associated with schizophrenia in Irish high density families. Am J Med Genet 2004; 129B:23-6.

55 Morris DW, Rodgers A, McGhee KA, Schwaiger S, Scully P, Quinn J, Meagher D, Waddington JL, Gill M, Corvin AP. Confirming RGS4 as a susceptibility gene for schizophrenia. Am J Med Genet 2004;125B:50-3.

56 Beyer CE, Ghavami A, Lin Q, Sung A, Rhodes KJ, Dawson LA, Schechter LE, Young KH. Regulators of G-protein signaling 4: modulation of 5-HT(1A)mediated neurotransmitter release in vivo. Brain Res 2004;1022:214-20.

57 De Blasi A, Conn PJ, Pin J, Nicoletti F. Molecular determinants of metabotropic glutamate receptor signaling. Trends Pharmacol Sci 2001;22:114-20.

58 Taymans JM, Kia HK, Claes R, Cruz C, Leysen J, Langlois X. Dopamine receptor-mediated regulation of RGS2 and RGS4 mRNA differentially depends on ascending dopamine projections and time. Eur J Neurosci 2004; 19:2249-60.

59 Thaminy S, Auerbach D, Arnoldo A, Stagljar I. Identification of novel ErbB3interacting factors using the split-ubiquitin membrane yeast two-hybrid system. Genome Res 2003:13:1744-53.

60 Brzustowicz LM, Simone J, Mohseni P, Hayter JE, Hodgkinson KA, Chow EW, Bassett AS. Linkage disequilibrium mapping of schizophrenia susceptibility to the CAPON region of chromosome 1q22. Am J Hum Genet 2004:74(5): 1057-63.

61 Gerber DJ, Hall D, Miyakawa T, Demars S, Gogos JA, Karayiorgou M, Tonegawa S. Evidence for association of schizophrenia with genetic variation in the 8 p21.3 gene, PPP3CC, encoding the calcineurin gamma subunit. Proc Natl Acad Sci U S A 2003;100:8993-8.

62 Duan J, Martinez M, Sanders AR, Hou C, Saitou N, Kitano T, Mowry BJ, Crowe RR, Silverman JM, Levinson DF, Gejman PV. Polymorphisms in the Trace Amine Receptor 4 (TRAR4) gene on chromosome 6q23.2 are associated with susceptibility to schizophrenia. Am J Hum Genet 2004:75:624-38.

63 Maclntyre DJ, Blackwood DH, Porteous DJ, Pickard BS, Muir WJ. Chromosomal abnormalities and mental illness. Mol Psychiatry 2003;8:275-87

64 Pulver AE, Nestadt G, Goldberg R, Shprintzen RJ, Lamacz M, Wolyniec PS, Morrow B, Karayiorgou M, Antonarakis SE, Housman D, Kucherlapati RJ. Psychotic illness in patients diagnosed with velo-cardio-facial syndrome and their relatives. J Nerv Ment Dis 1994;182:476-8.

65 Bassett AS, Hodgkinson K, Chow EW, Correia S, Scutt LE, Weksberg R. $22 \mathrm{q} 11$ deletion syndrome in adults with schizophrenia. Am J Med Genet 1998;81:328-37.

66 Murphy KC, Jones LA, Owen MJ. High rates of schizophrenia in adults with velo-cardio-facial syndrome. Arch Gen Psychiatry 1999:56:940-5.

67 Ivanov D, Kirov G, Norton N, Williams HJ, Williams NM, Nikolov I, Tzwetkova R, Stambolova SM, Murphy KC, Toncheva D, Thapar A, O'Donovan MC, Owen MJ. Chromosome 22q11 deletions, velo-cardiofacial syndrome and early-onset psychosis: molecular genetic study. Br J Psychiatry 2003:183:409-13.

68 Chen X, Wang X, O'Neill AF, Walsh D, Kendler KS. Variants in the catecholO-methyltransferase (COMT) gene are associated with schizophrenia in Irish high-density families. Mol Psychiatry 2004;9:962-7.

69 Egan MF, Goldberg TE, Kolachana BS, Callicott JH, Mazzanti CM, Straub RE, Goldman D, Weinberger DR. Effect of COMT Val 108/158 Met genotype on frontal lobe function and risk for schizophrenia. Proc Natl Acad Sci U S A 2001;98:6917-22.

70 Malhotra AK, Kestler L, Mazzanti C, Bates JA, Goldberg T, Goldman D. A functional polymorphism in the COMT gene and performance on a test of prefrontal cognition. Am J Psychiatry 2002;159:652-4.

71 Glatt SJ, Faraone SV, Tsuang MT. Association between a functional catechol O-methyltransferase gene polymorphism and schizophrenia: meta-analysis of case-control and family-based studies. Am J Psychiatry 2003; 160:469-76.

72 Li T, Ball D, Zhao J, Murray RM, Liu X, Sham PC, Collier DA. Family-based linkage disequilibrium mapping using SNP marker haplotypes: application to a potential locus for schizophrenia at chromosome 22q11. Mol Psychiatry 2000;5:452.

73 Shifman S, Bronstein M, Sternfeld M, Pisanté-Shalom A, Lev-Lehman E, Weizman A, Reznik I, Spivak B, Grisaru N, Karp L, Schiffer R, Kotler M, Strous RD, Swartz-Vanetik M, Knobler HY, Shinar E, Beckmann JS, Yakir B, Risch N, Zak NB, Darvasi A. A highly significant association between a COMT haplotype and schizophrenia. Am J Hum Genet 2002;71:1296-302.

74 Sanders AR, Rusu I, Duan J, Molen JE, Hou C, Schwab SG, Wildenauer DB, Martinez M, Gejman PV. Haplotypic association spanning the 22q11.21 genes COMT and ARVCF with schizophrenia. Mol Psychiatry 2004, Aug 31 [Epub ahead of print].

75 Handoko HY, Nyholt DR, Hayward NK, Nertney DA, Hannah DE, Windus LC, MCCormack CM, Smith HJ, Filippich C, James MR, Mowry BJ. Separate and interacting effects within the catechol-O-methyltransferase (COMT) are associated with schizophrenia. Mol Psychiatry 2004, Oct 26 [Epub ahead of print].

76 Lachman HM, Papolos DF, Saito T, Yu YM, Szumlanski CL, Weinshilboum RM. Human catechol-O-methyltransferase pharmacogenetics: description of a functional polymorphism and its potential application to neuropsychiatric disorders. Pharmacogenetics 1996;6(3):243-50

77 Gogos JA, Santha M, Takacs Z, Beck KD, Luine V, Lucas LR, Nadler JV, Karayiorgou $M$. The gene encoding proline dehydrogenase modulates sensorimotor gating in mice. Nat Genet 1999;21:434-9.

78 Jacquet H, Raux G, Thibaut F, Hecketsweiler B, Houy E, Demilly C, Haouzir S, Allio G, Fouldrin G, Drouin V, Bou J, Petit M, Campion D, Frebourg T. PRODH mutations and hyperprolinemia in a subset of schizophrenic patients. Hum Mol Genet 2002;11:2243-9.

79 Liu H, Heath SC, Sobin C, Roos JL, Galke BL, Blundell ML, Lenane M, Robertson B, Wijsman EM, Rapoport JL, Gogos JA, Karayiorgou M. Genetic variation at the 22q1 1 PRODH2/DGCR6 locus presents an unusual pattern and increases susceptibility to schizophrenia. Proc Natl Acad Sci U S A 2002;99:3717-22.

80 Li T, Ma X, Sham PC, Sun X, Hu X, Wang Q, Meng H, Deng W, Liu X, Murray RM, Collier DA. Evidence for association between novel polymorphisms in the PRODH gene and schizophrenia in a Chinese population. Am J Med Genet 2004;129B:13-5.

81 Williams HJ, Williams N, Spurlock G, Norton N, Ivanov D, McCreadie RG, Preece A, Sharkey V, Jones S, Zammit S, Nikolov I, Kehaiov I, Thapar A, Murphy KC, Kirov G, Owen MJ, O'Donovan MC. Association between PRODH and schizophrenia is not confirmed. Mol Psychiatry 2003;8:644-5.

82 Ohtsuki T, Tanaka S, Ishiguro H, Noguchi E, Arinami T, Tanabe E, Yara K, Okubo T, Takahashi S, Matsuura M, Sakai T, Muto M, Kojima T, Matsushima $\mathrm{E}$, Toru $\mathrm{M}$, Inada T. Failure to find association between PRODH deletion and schizophrenia. Schizophr Res 2004;67:111-3.

83 Jacquet H, Demily C, Houy E, Hecketsweiler B, Bou J, Raux G, Lerond J, Allio G, Haouzir S, Tillaux A, Bellegou C, Fouldrin G, Delamillieure P, Menard JF, Dollfus S, D'Amato T, Petit M, Thibaut F, Frebourg T, Campion D. Hyperprolinemia is a risk factor for schizoaffective disorder. Mol Psychiatry 2004, Oct 19 [Epub ahead of print].

84 Mukai J, Liu H, Burt RA, Swor DE, Lai WS, Karayiorgou M, Gogos JA. Evidence that the gene encoding ZDHHC8 contributes to the risk of schizophrenia. Nat Genet 2004;36:725-31.

85 Chen WY, Shi YY, Zheng YL, Zhao XZ, Zhang GJ, Chen SQ, Yang PD, He L. Case-control study and transmission disequilibrium test provide consistent evidence for association between schizophrenia and genetic variation in the 22q1 1 gene ZDHHC8. Hum Mol Genet 2004;13(23):2991-5.

86 Blackwood DH, Fordyce A, Walker MT, St Clair DM, Porteous DJ, Muir WJ. Schizophrenia and affective disorders - cosegregation with a translocation at chromosome 1q42 that directly disrupts brain-expressed genes: clinical and P300 findings in a family. Am J Hum Genet 2001;69:428-33.

87 Millar JK, Wilson-Annan JC, Anderson S, Christie S, Taylor MS, Semple CA Devon RS, Clair DM, Muir WJ, Blackwood DH, Porteous DJ. Disruption of two novel genes by a translocation co-segregating with schizophrenia. Hum Mol Genet 2000;9:1415-23.

88 Ekelund J, Hovatta I, Parker A, Paunio T, Varilo T, Martin R, Suhonen J, Ellonen $P$, Chan $G$, Sinsheimer JS, Sobel E, Juvonen $H$, Arajarvi $R$, Partonen T, Suvisaari J, Lonngvist J, Meyer J, Peltonen L. Chromosome 1 loci in Finnish schizophrenia families. Hum Mol Genet 2001;10:1611-7.

89 Ekelund J, Hennah W, Hiekkalinna T, Parker A, Meyer J, Lonnqvist J, Peltonen L. Replication of 1q42 linkage in Finnish schizophrenia pedigrees. Mol Psychiatry 2004;9(11):1037-41.

90 Miyoshi K, Honda A, Baba K, Taniguchi M, Oono K, Fujita T, Kuroda S, Katayama T, Tohyama M. Disrupted-In-Schizophrenia 1, a candidate gene for schizophrenia, participates in neurite outgrowth. Mol Psychiatry 2003:8:685-94

91 Ozeki Y, Tomoda T, Kleiderlein J, Kamiya A, Bord L, Fujii K, Okawa M, Yamada N, Hatten ME, Snyder SH, Ross CA, Sawa A. Disrupted-inschizophrenia-1 (DISC-1): mutant truncation prevents binding to NudE-like (NUDEL) and inhibits neurite outgrowth. Proc Natl Acad Sci U S A 2003;100:289-94

92 Devon RS, Anderson S, Teague PW, Burgess P, Kipari TM, Semple CA, Millar JK, Muir WJ, Murray V, Pelosi AJ, Blackwood DH, Porteous DJ. Identification of polymorphisms within Disrupted in Schizophrenia 1 and Disrupted in Schizophrenia 2, and an investigation of their association with schizophrenia and bipolar disorder. Psychiatr Genet 2002;11:71-8

93 Kockelkorn $\Pi$, Arai M, Matsumoto H, Fukuda N, Yamada K, Minabe Y, Toyota T, Ujike H, Sora I, Mori N, Yoshikawa T, Itokawa M. Association 
study of polymorphisms in the $5^{\prime}$ upstream region of human $\mathrm{DISCl}$ gene with schizophrenia. Neurosci Lett 2004;368(1):41-5.

94 Hennah W, Varilo T, Kestila M, Paunio T, Arajarvi R, Haukka J, Parker A Martin R, Levitzky S, Partonen T, Meyer J, Lonnqvist J, Peltonen L, Ekelund J. Haplotype transmission analysis provides evidence of association for DISC1 to schizophrenia and suggests sex-dependent effects. Hum Mol Genet 2003;12:3151-9.

95 Hodgkinson CA, Goldman D, Jaeger J, Persaud S, Kane JM, Lipsky RH, Malhotra AK. Dissupted in schizophrenia 1 (DISC1): association with schizophrenia, schizoaffective disorder, and bipolar disorder. Am J Hum Genet 2004;75(5):862-72.

96 Craddock N, Jones I. Genetics of bipolar disorder. J Med Genet 1999;36:585-94.

97 Jones I, Kent L, Craddock N. Genetics of affective disorders, In: McGuffin P, Owen M, Gottesman II, eds. Psychiatric genetics and genomics. Oxford: Oxford University Press, 2002:21 1-245.

98 McGuffin $P$, Katz R. The genetics of depression and manic-depressive disorder. Br J Psychiatry 1989:155:294-304.

99 McGuffin P, Rijsdijk F, Andrew M, Sham P, Katz R, Cardno A. The heritability of bipolar affective disorder and the genetic relationship to unipolar depression. Arch Gen Psychiatry 2003;60(5):497-502.

100 Kieseppa T, Partonen T, Haukka J, Kaprio J, Lonnqvist J. High concordance of bipolar I disorder in a nationwide sample of twins. Am J Psychiatry 2004;161(10):1814-21.

101 Craddock N, Khodel V, Van Eerdewegh P, Reich T. Mathematical limits of multilocus models: the genetic transmission of bipolar disorder. Am J Hum Genet 1995:57:690-702

102 Segurado R, Detera-Wadleigh SD, Levinson DF, Lewis CM, Gill M Nurnberger JI Jr, Craddock N, DePaulo JR, Baron M, Gershon ES, Ekholm J, Cichon S, Turecki G, Claes S, Kelsoe JR, Schofield PR, Badenhop RF, Morissette J, Coon H, Blackwood D, Mclnnes LA, Foroud T, Edenberg HJ, Reich T, Rice JP, Goate A, Mclnnis MG, McMahon FJ, Badner JA, Goldin LR, Bennett P, Willour VL, Zandi PP, Liu J, Gilliam C, Juo SH, Berrettini WH, Yoshikawa T, Peltonen L, Lonnqvist J, Nothen MM, Schumacher J, Windemuth C, Rietschel M, Propping P, Maier W, Alda M, Grof' P, Rouleau GA, Del-Favero J, Van Broeckhoven C, Mendlewicz J, Adolfsson R, Spence MA, Luebbert $\mathrm{H}$, Adams $\mathrm{L}$, Donald JA, Mitchell PB, Barden N, Shink E, Byerley W, Muir W, Visscher PM, Macgregor S, Gurling H, Kalsi G, McQuillin A, Escamilla MA, Reus VI, Leon P, Freimer NB, Ewald H, Kruse TA, Mors O, Radhakrishna U, Blouin JL, Antonarakis SE, Ákarsu N. Genome scan meta-analysis of schizophrenia and bipolar disorder, part iii: bipolar disorder. Am J Hum Genet 2003:73(1):49-62.

103 Ewald H, Flint T, Kruse TA, Mors O. A genome-wide scan shows significant linkage between bipolar disorder and chromosome 12q24.3 and suggestive linkage to chromosomes 1p22-21, 4p16, 6q14-22, 10q26 and 16p13.3. Mol Psychiatry 2002;7(7):734-44.

104 Shink E, Morissette J, Sherrington R, Barden N. A genome-wide scan points to a susceptibility locus for bipolar disorder on chromosome 12. Mol Psychiatry 2004, Oct 19 [Epub ahead of print].

105 Craddock N, Owen M, Burge S, Kurian B, Thomas P, McGuffin P. Familial cosegregation of major affective disorder and Darier's disease (keratosis follicularis). Br J Psychiatry 1994;164:355-8.

106 Jones I, Jacobsen N, Green EK, Elvidge GP, Owen MJ, Craddock N. Evidence for familial cosegregation of major affective disorder and genetic markers flanking the gene for Darier's disease. Mol Psychiatry 2002;7:424-7.

107 Green E, Elvidge G, Jacobsen N, Glaser B, Jones I, O'Donovan MC, Kirov G, Owen MJ, Craddock N. Localization of bipolar susceptibility locus by molecular genetic analysis of the chromosome 12q23-24 region in two pedigrees with bipolar disorder and Darier's disease. Am J Psychiatry 2005; 162(1):35-42.

108 Craddock N, Dave S, Greening J. Association studies of bipolar disorder. Bipolar Disord 2001;3:284-98.

109 Preisig M, Bellivier F, Fenton BT, Baud P, Berney A, Courtet P, Hardy P, Golaz J, Leboyer M, Mallet J, Matthey ML, Mouthon D Neidhart E, NostenBertrand M, Stadelmann-Dubuis E, Guimon J, Ferrero F, Buresi C, Malafosse A. Association between bipolar disorder and monoamine oxidase A gene polymorphisms: results of a multicenter study. Am J Psychiatry 2000;157:948-55.

110 Jones I, Craddock N. Candidate gene studies of bipolar disorder. Ann Med $2001 ; 33: 248-56$.

111 Anguelova M, Benkelfat C, Turecki G. A systematic review for association studies investigating genes coding for serotonin receptors and the serotonin transporter: I. Affective disorders. Mol Psychiatry 2003:8:574-91.

112 Lasky-Su JA, Faraone SV, Glatt SJ, Tsuang MT. Meta-analysis of the association between two polymorphisms in the serotonin transporter gene and affective disorders. Am J Med Genet 2004, Dec 2 [Epub ahead of print].

113 Shifman S, Bronstein M, Sternfeld M, Pisante A, Weizman A, Reznik I, Spivak B, Grisaru N, Karp L, Schiffer R, Kotler M, Strous RD, SwartzVanetik M, Knobler HY, Shinar E, Yakir B, Zak NB, Darvasi A. COMT: a common susceptibility gene in bipolar disorder and schizophrenia. Am J Med Genet 2004;128B(1):61-4.

114 Hattori E, Liu C, Badner JA, Bonner TI, Christian SL, Maheshwari M, DeteraWadleigh SD, Gibbs RA, Gershon ES. Polymorphisms at the G72/G30 gene locus, on 13q33, are associated with bipolar disorder in two independent pedigree series. Am J Hum Genet 2003;72:1131-40.

115 Chen YS, Akula N, Detera-Wadleigh SD, Schulze TG, Thomas J, Potash JB, DePaulo JR, Mclnnis MG, Cox NJ, McMahon FJ. Findings in an independen sample support an association between bipolar affective disorder and the G72/G30 locus on chromosome 13q33. Mol Psychiatry 2004;9:87-92.
116 Green EK, Dimitrova A, Grozeva D, McGregor S, Nikolov I, Dwyer S, Preece A, Norton N, Williams $H$, Williams NM, Jones L, Jones I, O'Donovan MC, Owen MJ, Kirov G, Craddock N. Evidence for linkage disequilibrium at both $\mathrm{G} 72 / \mathrm{G} 30$ and D-amino acid oxidase with genetic risk for bipolar disorder (abstract). Am J Med Genet 2004;130B(1):26.

117 Green E, Craddock N. Brain-derived neurotrophic factor as a potential risk locus for bipolar disorder: evidence, limitations, and implications. Curr Psychiatry Rep 2003;5(6):469-76.

118 Duman RS. The neurochemistry of mood disorders: preclinical studies. In: Charney DS, Nestler EJ, Bunney BS, eds. The neurobiology of mental illness. New York: Oxford University Press, 1999:333-47.

119 Seidah NG, Benjannet S, Pareek S, Chretien M, Murphy RA. Cellular processing of the neurotrophin precursors of NT3 and BDNF by the mammalian proprotein convertases. FEBS Lett 1996;379:247-50.

120 Egan MF, Kojima M, Callicott JH, Goldberg TE, Kolachana BS, Zaistev E, Bertolino A, Gol B, Goldman D, Dean M, Lu B, Weinberger DR. The BDNF Val66Met polymorphism affects activity-dependent secretion of BDNF and human memory and hippocampal function. Cell 2003;112:257-69.

121 Sklar P, Gabriel SB, Mclnnis MG, Bennett P, Lim YM, Tsan G, Schaffner S, Kirov G, Jones I, Owen M, Craddock N, DePaulo JR, Lander ES. Familybased association study of 76 candidate genes in bipolar disorder: BDNF is a potential risk locus. Brain-derived neurotrophic factor. Mol Psychiatry 2002; 7:579-93

122 Neves-Pereira M, Mundo E, Muglia P, King N, Macciardi F, Kennedy JL. The brain-derived neurotrophic factor gene confers susceptibility to bipolar disorder: evidence from a family-based association study. Am J Hum Genet 2002;71:651-5.

123 Geller B, Badner JA, Tillman R, Christian SL, Bolhofner K, Cook EH Jr. Linkage disequilibrium of the brain-derived neurotrophic factor Val66Met polymorphism in children with a prepubertal and early adolescent bipolar disorder phenotype. Am J Psychiatry 2004;161(9):1698-700.

124 Oswald P, Del-Favero J, Massat I, Souery D, Claes S, Van Broeckhoven C, Mendlewicz J. Non-replication of the brain-derived neurotrophic factor (BDNF) association in bipolar affective disorder: a Belgian patient-control study. Am J Med Genet 2004;129B(1):34-5.

125 Skibinska M, Hauser J, Czerski PM, Leszczynska-Rodziewicz A, Kosmowska M, Kapelski P, Slopien A, Zakrzewska M, Rybakowski JK Association analysis of brain-derived neurotrophic factor (BDNF) gene Val66Met polymorphism in schizophrenia and bipolar affective disorder. World J Biol Psychiatry 2004;5(4):215-20.

126 Hong CJ, Huo SJ, Yen FC, Tung CL, Pan GM, Tsai SJ. Association study of a brain-derived neurotrophic-factor genetic polymorphism and mood disorders, age of onset and suicidal behavior. Neuropsychobiology 2003;48(4): 186-9.

127 Nakata K, Ujike H, Sakai A, Uchida N, Nomura A, Imamura T, Katsu T, Tanaka Y, Hamamura T, Kuroda S. Association study of brain-derived neurotrophic factor (BDNF) gene with bipolar disorder. Neurosci Lett 2003;337:17-20.

128 Barrett TB, Hauger RL, Kennedy JL, Sadovnick AD, Remick RA, Keck PE, McElroy SL, Alexander M, Shaw SH, Kelsoe JR. Evidence that a single nucleotide polymorphism in the promoter of the $G$ protein receptor kinase 3 gene is associated with bipolar disorder. Mol Psychiatry 2003;8(5):546-57.

129 Kakiuchi C, Iwamoto K, Ishiwata M, Bundo M, Kasahara T, Kusumi I, Tsujita T, Ókazaki Y, Nanko S, Kunugi H, Sasaki T, Kato T. Impaired feedback regulation of XBP1 as a genetic risk factor for bipolar disorder. Nat Genet 2003;35(2):171-5

130 Cichon S, Buervenich S, Kirov G, Akula N, Dimitrova A, Green E, Schumacher J, Klopp N, Becker T, Ohlraun S, Schulze TG, Tullius M, Gross MM, Jones L, Krastev S, Nikolov I, Hamshere M, Jones I, Czerski PM, Leszczynska-Rodziewicz A, Kapelski P, Bogaert AV, Illig T, Hauser J, Maier W, Berrettini W, Byerley W, Coryell W, Gershon ES, Kelsoe JR, Mclnnis MG, Murphy DL, Nurnberger Jl, Reich T, Scheftner W, O'Donovan MC, Propping P, Owen MJ', Rietschel M, Nothen MM, McMahon FJ, Craddock N. Lack of support for a genetic association of the XBP1 promoter polymorphism with bipolar disorder in probands of European origin. Nat Genet 2004;36(8):783-4.

131 Barden N, Harvey M, Shink E, Tremblay M, Gagné B, Raymond C, Labbé M, St-Onge L, Stadler H, Sillaber I, Paez-Pareda M, Muller-Mysok B, Binder E, Holsboer F. Identification and characterisation of a gene predisposing to both bipolar and unipolar affective disorders (abstract). Am J Med Gen 2004; 130B(1): 122.

132 Kirov G, Murphy KC, Arranz MJ, Jones I, McCandles F, Kunugi H, Murray RM, McGuffin P, Collier DA, Owen MJ, Craddock N. Low activity allele of catechol-O-methyltransferase gene associated with rapid cycling bipolar disorder. Mol Psychiatry 1998;3:342-5.

133 Turecki G, Grof P, Grof E, D’Souza V, Lebuis L, Marineau C, Cavazzoni P, Duffy A, Betard C, Zvolsky P, Robertson C, Brewer C, Hudson TJ Rouleau GA, Alda M. Mapping susceptibility genes for bipolar disorder: a pharmacogenetic approach based on excellent response to lithium. Mol Psychiatry 2001;6(5):570-8.

134 Jones I, Craddock N. Familiality of the puerperal trigger in bipolar disorder: results of a family study. Am J Psychiatry 2001;158:913-7.

135 Coyle N, Jones I, Robertson E, Lendon C, Craddock N. Variation at the serotonin transporter gene influences susceptibility to bipolar affective puerperal psychosis. Lancet 2000;356:1490-1.

136 Faraone SV, Glatt SJ, Su J, Tsuang MT. Three potential susceptibility loci shown by a genome-wide scan for regions influencing the age at onset of mania. Am J Psychiatry 2004;161(4):625-30.

137 O'Mahony E, Corvin A, O'Connell R, Comerford C, Larsen B, Jones R, McCandless F, Kirov G, Cardno AG, Craddock N, Gill M. Sibling pairs with 
affective disorders: resemblance of demographic and clinical features. Psychol Med 2002;32(1):55-61.

138 Craddock N, Jones I, Kirov G, Jones L. The Bipolar Affective Disorder Dimension Scale (BADDS) - a dimensional scale for rating lifetime psychopathology in bipolar spectrum disorders. BMC Psychiatry 2004;4:19.

139 Potash JB, Zandi PP, Willour VL, Lan TH, Huo Y, Avramopoulos D, Shugart YY, MacKinnon DF, Simpson SG, McMahon FJ, DePaulo JR Jr, Mclnnis MG. Suggestive linkage to chromosomal regions $13 q 31$ and $22 q 12$ in families with psychotic bipolar disorder. Am J Psychiatry 2003;160(4):680-6

140 Kraepelin E. Manic-depressive insanity and paranoia (trans. Barclay RM). Edinburgh: Livingstone, 1919

141 American Psychiatric Association. Diagnostic and statistical manual of mental disorders, 4th ed. Washington, DC: American Psychiatric Press, 1994.

142 WHO. The ICD10 classification of mental and behavioural disorders. Geneva: World Health Organization, 1993.

143 Crow TJ. The continuum of psychosis and its genetic origins. The sixty-fifth Maudsley lecture. Br J Psychiatry 1990:156:788-97.

144 Gershon ES, Hamovit J, Guroff JJ, Dibble E, Leckman JF, Sceery W, Targum SD, Nurnberger JI Jr, Goldin LR, Bunney WE Jr. family study of schizoaffective, bipolar I, bipolar II, unipolar, and normal control probands. Arch Gen Psychiatry 1982;39:1157-67.

145 Frangos $E$, Athanassenas G, Tsitourides S, Katsanou N, Alexandrakou P. Prevalence of DSM III schizophrenia among the first-degree relatives of schizophrenic probands. Acta Psychiatr Scand 1985;72:382-6.

146 Baron M, Gruen R, Asnis L, Kane J. Schizoaffective illness, schizophrenia and affective disorders: morbidity risk and genetic transmission. Acta Psychiatr Scand 1982:65:253-62.

147 Pope HG Jr, Yurgelun-Todd D. Schizophrenic individuals with bipolar firstdegree relatives: analysis of two pedigrees. I Clin Psychiatry 1990:51:97-101.

148 Tsuang MT, Winokur G, Crowe RR. Morbidity risks of schizophrenia and affective disorders among first degree relatives of patients with schizophrenia, mania, depression and surgical conditions. $\mathrm{Br} J$ Psychiatry 1980;137:497-504

149 Valles V, Van Os J, Guillamat R, Gutiérrez B, Campillo M, Gento P, Fañanás $L$. Increased morbid risk for schizophrenia in families of in-patients with bipolar illness. Schizophr Res 2000;42:83-90.

150 Kendler KS, Karkowski LM, Walsh D. The structure of psychosis: latent class analysis of probands from the Roscommon Family Study. Arch Gen Psychiatry 1998:55:492-9.

151 Rice J, Reich T, Andreasen NC, Endicoft J, Van Eerdewegh M, Fishman R, Hirschfeld RM, Klerman GL. The familial transmission of bipolar illness. Arch Gen Psychiatry 1987;44:441-7.

152 Cardno AG, Rijsdijk FV, Sham PC, Murray RM, McGuffin P. A twin study of genetic relationships between psychotic symptoms. Am J Psychiatry 2002;159:539-45.

153 McGuffin P, Reveley A, Holland A. Identical triplets: non-identical psychosis? Br J Psychiatry 1982;140:1-6.

154 Berrettini W. Evidence for shared susceptibility in bipolar disorder and schizophrenia. Am J Med Genet 2003;123C:59-64.

155 Hamshere ML, Williams NM, Segurado R, Lambert D, Jones LA, Holmans P, Kirov G, Corvin A, Jones I, O'Donovan MC, Gill M, Owen MJ, Craddock N.' Evidence for linkage $(L O D=3.54)$ at IQ42 close to $\mathrm{DISC1}$ in a genome scan of functional psychosis pedigrees including at least one member with schizoaffective disorder of bipolar type (abstract). Am J Med Genet 2004; 130B(1):127.

156 Macgregor S, Visscher PM, Knott SA, Thomson P, Porteous DJ, Millar JK, Devon RS, Blackwood D, Muir WJ. A genome scan and follow-up study identify a bipolar disorder susceptibility locus on chromosome 1q42. Mol Psychiatry 2004;9(12):1083-90.

157 Green EK, Raybould R, Macgregor S, Gordon-Smith K, Heron J, Hyde S, Grozeva D, Hamshere M, Williams N, Owen MJ, O'Donovan MC, Jones L, Jones I, Kirov G, Craddock N. The schizophrenia susceptibility gene, Neuregulin 1 (NRG1), operates across traditional diagnostic boundaries to increase risk for bipolar disorder. Arch Gen Psychiatry (in press).

158 Bakker SC, Hoogendoorn MLC, Selten J-P, Verduijn W, Pearson PL, Sinke RJ, Kahn RS. Neuregulin 1: genetic support for schizophrenia subtypes. Mol Psychiatry 2004;9:1061-3.

159 Craddock N, Owen MJ. The beginning of the end for the Kraepelinian dichotomy. Br J Psychiatry (in press).

160 Harrison PJ, Owen MJ. Genes for schizophrenia? Recent findings and their pathophysiological implications. Lancet 2003;361(9355):417-9.
161 Silventoinen K, Sammalisto S, Perola M, Boomsma DI, Cornes BK, Davis C, Dunkel L, De Lange M, Harris JR, Hielmborg JV, Luciano M, Martin NG Mortensen J, Nistico L, Pedersen NL, Skytthe A, Spector TD, Stazi MA, Willemsen G, Kaprio J. Heritability of adult body height: a comparative study of twin cohorts in eight countries. Twin Res 2003;6(5):399-408.

162 Kyvik KO, Green A, Beck-Nielsen H. Concordance rates of insulin dependent diabetes mellitus: a population based study of young Danish twins. BMJ 1995;311(7010):913-7.

163 Hyttinen V, Kaprio J, Kinnunen L, Koskenvuo M, Tuomilehto J. Genetic liability of type 1 diabetes and the onset age among 22,650 young Finnish twin pairs: a nationwide follow-up study. Diabetes 2003;52(4):1052-5.

164 Locatelli I, Lichtenstein P, Yashin Al. The heritability of breast cancer: a Bayesian correlated frailty model applied to Swedish twins data. Twin Res 2004:7(2):182-91.

165 Zdravkovic S, Wienke A, Pedersen NL. Heritability of death from coronary heart disease: a 36-year follow-up of 20966 Swedish twins. J Intern Med 2002;252(3):247-54.

166 Poulsen P, Kyvik KO, Vaag A, Beck-Nielsen H. Heritability of type II (noninsulin-dependent) diabetes mellitus and abnormal glucose tolerance - a population-based twin study. Diabetologia 1999;42(2): 139-45.

167 Radhakrishna U, Senol S, Herken H, Gucuyener K, Gehrig C, Blouin JL, Akarsu NA, Antonarakis SE. An apparently dominant bipolar affective disorder (BPAD) locus on chromosome 20p11.2-q11.2 in a large Turkish pedigree. Eur J Hum Genet 2001:9(1):39-44.

168 Adams LJ, Mitchell PB, Fielder SL, Rosso A, Donald JA, Schofield PR. A susceptibility locus for bipolar affective disorder on chromosome $4 \mathrm{q} 35$. Am J Hum Genet 1998;62(5): 1084-91.

169 Blackwood DH, He L, Morris SW, Mclean A, Whitton C, Thomson M, Walker MT, Woodburn K, Sharp CM, Wright AF, Shibasaki Y, St Clair DM, Porteous DJ, Muir WJ. A locus for bipolar affective disorder on chromosome 4p. Nat Genet 1996;12(4):427-30.

170 Lambert DBJ, Hamshere ML, Segurado R, Bennett P, Jones I, McCandless F, Jones L, Raybould R, Heron J, Green E, Nokolov I, Corvin A, O'Mahony E, Owen M, Middle F, Kirov G, Holmans P, Craddock N, Gill M. The Wellcome Trust Ireland/UK bipolar disorder sibling pair study: stage II analysis (abstract). Am J Med Genet 2004;130B:51.

171 Fallin MD, Lasseter VK, Wolyniec PS, McGrath JA, Nestadt G, Valle D, Liang KY, Pulver AE. Genomewide linkage scan for bipolar-disorder susceptibility loci among Ashkenazi Jewish families. Am J Hum Genet 2004;75(2):204-19.

172 Middleton FA, Pato MT, Gentile KL, Morley CP, Zhao X, Eisener AF, Brown A, Petryshen TL, Kirby AN, Medeiros H, Carvalho C, Macedo A, Dourado A, Coelho I, Valente J, Soares MJ, Ferreira CP, Lei M, Azevedo MH, Kennedy JL, Daly MJ, Sklar P, Pato CN. Genomewide linkage analysis of bipolar disorder by use of a high-density single-nucleotide-polymorphism (SNP) genotyping assay: a comparison with microsatellite marker assays and finding of significant linkage to chromosome 6q22. Am J Hum Genet 2004;74(5):886-97.

173 Dick DM, Foroud T, Flury L, Bowman ES, Miller MJ, Rau NL, Moe PR, Samavedy N, El-Malllakh R, Manii H, Glitz DA, Meyer ET, Smiley C, Hahn R, Widmark C, McKinney R, Sutton L, Ballas C, Grice D, Berrettini W, Byerley W, Coryell W, DePaulo R, MacKinnon DF, Gershon ES, Kelsoe JR, McMahon FJ, Mclnnis M, Murphy DL, Reich T, Scheftner W, Nurnberger JI Jr. Genomewide linkage analyses of bipolar disorder: a new sample of 250 pedigrees from the National Institute of Mental Health Genetics Initiative. Am J Hum Genet 2003;73(1):107-14 (erratum in: Am J Hum Genet 2003:73(4):979).

174 Dick DM, Foroud T, Edenberg HJ, Miller M, Bowman E, Rau NL, DePaulo JR, Mclnnis M, Gershon E, McMahon F, Rice JP, Bierut L, Reich T, Nurnberger J Jr. Apparent replication of suggestive linkage on chromosome 16 in the NIMH genetics initiative bipolar pedigrees. Am J Med Genet 2002;114(4):407-12.

175 Willour VL, Zandi PP, Huo Y, Diggs TL, Chellis JL, MacKinnon DF, Simpson SG, McMahon FJ, Potash JB, Gershon ES, Reich T, Foroud T, Nurnberger JI Jr, DePaulo JR Jr, Mclnnis MG. enome scan of the fiffy-six bipolar pedigrees from the NIMH genetics initiative replication sample: chromosomes 4, 7, 9, 18, 19, 20, and 21. Am J Med Genet 2003;121B(1):21-7.

176 Zandi PP, Willour VL, Huo Y, Chellis J, Potash JB, MacKinnon DF, Simpson SG, McMahon FJ, Gershon E, Reich T, Foroud T, Nurnberger J Jr, DePaulo JR Jr. Mclnnis MG, National Institute of Mental Health Genetics Initiative Bipolar Group. Genome scan of a second wave of NIMH genetics initiative bipolar pedigrees: chromosomes 2, 11, 13, 14, and X. Am J Med Genet 2003;119B(1):69-76. 